\title{
46. PETROLOGY AND GEOCHEMISTRY OF BASALTS FROM ODP LEG 105, HOLE 647A, LABRADOR SEA AND THE DAVIS STRAIT AREA ${ }^{1}$
}

\author{
D. B. Clarke, ${ }^{2}$ B. I. Cameron, ${ }^{2}$ G. K. Muecke, ${ }^{2}$ and J. L. Bates ${ }^{3}$
}

\begin{abstract}
Basalt samples recovered from the lowermost $37 \mathrm{~m}$ of Leg 105 Hole $647 \mathrm{~A}$ in the Labrador Sea are fine- to mediumgrained, have microphenocrysts of clinopyroxene, and show little evidence of alteration. Chemically, these rocks are low potassium (0.01- $0.09 \mathrm{wt} \% \mathrm{~K}_{2} \mathrm{O}$ ), olivine- to quartz-normative tholeiites that are also depleted in other incompatible elements. In terms of many of the incompatible trace elements, the Labrador Sea samples are similar both to $N$-type midocean ridge basalts (MORBs) and to the terrestrial Paleocene volcanic rocks in the Davis Strait region of Baffin Island and West Greenland. However, significant differences are found in their strontium and neodymium isotope systematics. Hole 647A samples are more depleted in $\epsilon \mathrm{Nd}(+9.3)$ and are anomalously rich in ${ }^{87} \mathrm{Sr} /{ }^{86} \mathrm{Sr}(0.7040)$ relative to the Davis Strait basalts $\left(\epsilon \mathrm{Nd}+2.54\right.$ to +8.97 ; mean $\left.{ }^{87} \mathrm{Sr} /{ }^{86} \mathrm{Sr}, 0.7034\right)$. We conclude that the Hole $647 \mathrm{~A}$ and Davis Strait basalts may have been derived from a similar depleted mantle source composition. In addition, the Davis Strait magmas were generated from mantle of more than one composition. We also suggest that there is no geochemical evidence from the Hole 647A samples to support or to refute the existence of foundered continental crust in the Labrador Sea.
\end{abstract}

\section{INTRODUCTION}

\section{Geology of the Labrador Sea}

The origin of the Labrador Sea has been the subject of considerable controversy since the beginning of this century. Disagreement has centered largely over whether the floor of the Labrador Sea is foundered continental crust (Suess, 1906; Kerr, 1967; Meyerhoff, 1973) or whether it is new (oceanic) crust (Wegener, 1924; Clarke, 1969; LePichon et al., 1971; Srivastava et al., 1981). The advent of seismic reflection and refraction studies (Johnson et al., 1982), definition of magnetic lineations (Vogt and Avery, 1974; Srivastava, 1986), thermal subsidence patterns (Royden and Keen, 1980), and recovery of basaltic basement rocks by the Deep Sea Drilling Program (Laughton et al., 1972) strengthened the argument for an origin of the Labrador Sea by seafloor spreading. However, debate about the petrological nature of the Labrador Sea crust has never been considered with the benefit of fresh rock samples, modern trace-element studies, or isotopic data. This paper contributes these new perspectives to the debate.

The late Phanerozoic igneous history of the opening of the Labrador Sea may be subdivided into three geographical/temporal groups that become progressively younger toward the axis of the Labrador Sea. The first of these is manifest as volumetrically small, highly alkaline lamprophyres, kimberlites, and carbonatites of Jurassic-Cretaceous age (190-115 Ma) that cut the Precambrian basement of both coastal Labrador and southwest Greenland (King and McMillan, 1975; Leech et al., 1963; Larsen and Moller, 1968; Emeleus and Andrews, 1975; Clarke, 1977; Hansen, 1980). The second is found as basic volcanic units of Jurassic-Cretaceous age recovered in well cuttings from the continental shelves of both Labrador and southwest Greenland (Muecke et al., unpublished data). The third consists of the basalts of the new oceanic crust of the Labrador Sea floor, defined magnetically as occurring between Chron 34 (Late Creta-

\footnotetext{
${ }^{1}$ Srivastava. S. P., Arthur, M., Clement, B., et al., 1989. Proc. ODP, Sci. Results, 105: College Station, TX (Ocean Drilling Program).

2 Department of Geology, Dalhousie University, Halifax, Nova Scotia B3H 3J5, Canada.

${ }^{3}$ Nova Scotia Department of Mines and Energy, P.O. Box 1087, Halifax, Nova Scotia B3J 2X1, Canada.
}

ceous-Campanian, $84 \mathrm{Ma}$ ) and Chron 13 (early Oligocene, 36 Ma). The floor of the Labrador Sea is blanketed with thick sediments and to date, only a few basement samples have been recovered and studied (Laughton et al., 1972). Our purpose here is (1) to describe the recently obtained and most important samples yet recovered from the Labrador Sea basement, (2) to compare them with the Baffin Island-West Greenland (BI-WG) suite of the same age from the Davis Strait region, and (3) to interpret all of these rocks in terms of their petrogenetic and tectonic significance.

\section{Hole 647A}

Hole $647 \mathrm{~A}$ is located at $53^{\circ} 19.876^{\prime} \mathrm{N}, 45^{\circ} 15.717^{\prime} \mathrm{W}$, near magnetic anomaly 24 (55-58.6 Ma) and considerably south of the extinct spreading axis in the Labrador Sea (Fig. 1). The biostratigraphic age of the sediments immediately overlying the basalts is lower Eocene (55-56 Ma; Srivastava, Arthur, et al., 1987). Total penetration of the drill hole was $736 \mathrm{~m}$, of which only the deepest $37 \mathrm{~m}$ was in volcanic basement. Twenty samples of basaltic material were obtained for detailed petrological and geochemical study.

\section{PETROLOGY}

\section{Petrography}

Sampling of the core was governed by two criteria: that samples be taken at regular intervals and that every apparent lithological variation be included in the sample set. The sample locations and a summary of the petrography are given in Table 1 . In general, the basaltic rocks can be divided into six textural types along the length of the core:

1. Chill, very fine-grained, aphyric, microlitic, and variolitic texture with carbonate in vesicles, and both carbonate and chlorite in fractures (Cores 105-647A-71R-2 and 105-647A-71R-3).

2. Aphyric I, fine- to medium-grained (1-1.5 mm), intergranular texture with altered brown material in interstitial areas (Cores 105-647A-72R-1 to 105-647A-72R-3) (Pl. 1).

3. Glomerophyric, medium-grained ( $2 \mathrm{~mm})$, intergranular texture with interstitial dark areas of alteration and patchy inclusions of finer-grained $(0.75 \mathrm{~mm})$ holocrystalline, variolitic(?) basalt free of secondary minerals (Core 105-647A-72R-4) (Pl. 2). 


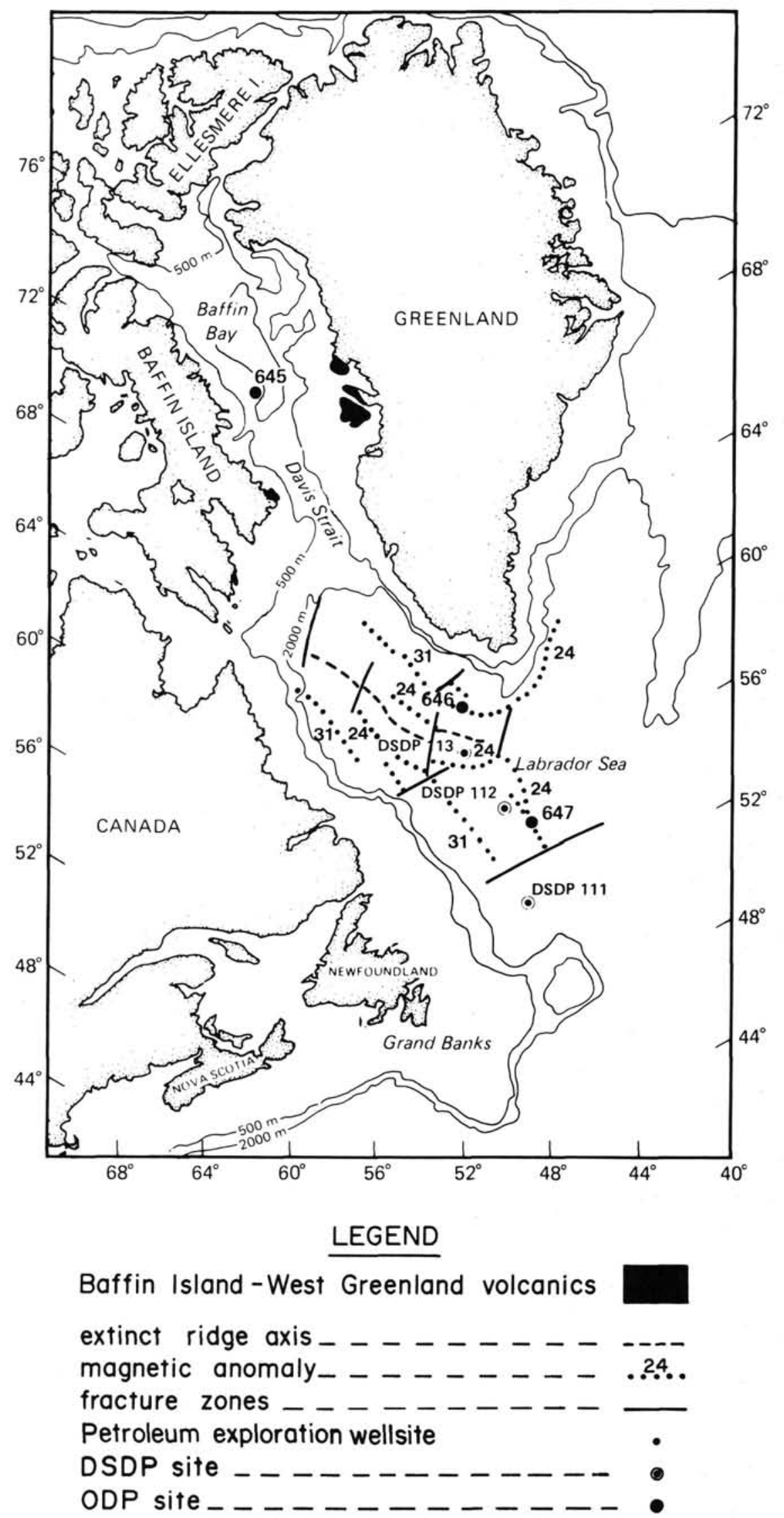

Figure 1. Map of the Labrador Sea showing magnetic lineations and location of the Hole 647A drill hole (after Srivastava, Arthur, et al., 1987). 
Table 1. Petrographic summary of the Site 647A basalts.

\begin{tabular}{|c|c|c|c|c|c|c|c|}
\hline Sample & $\begin{array}{l}\text { Depth } \\
\text { (mbsf) }\end{array}$ & Description & $\mathrm{E}$ & $\mathrm{M}$ & XT & NT & I \\
\hline 71R02 & 699.2 & $\begin{array}{l}\text { Very fine-grained ( }<0.05 \mathrm{~mm}) \text {, aphyric; } \\
\text { plagioclase needles with feathery } \\
\text { clinopyroxene and devitrified, altered glass; } \\
\text { carbonate and chlorite in vesicles and } \\
\text { veinlets. }\end{array}$ & & & & & \\
\hline $71 \mathrm{R} 03$ & 700.3 & $\begin{array}{l}\text { Very fine-grained, feathery clinopyroxene and } \\
\text { microlitic plagioclase; strongly oxidized. }\end{array}$ & & & & & \\
\hline $72 \mathrm{R} 01$ & 701.6 & $\begin{array}{l}\text { Fine- to medium-grained (1 mm), intergranular, } \\
\text { aphyric texture; plagioclase laths (An68) } \\
\text { and subhedral clinopyroxene; dark } \\
\text { interstitial patches. }\end{array}$ & $\mathbf{x}$ & $x$ & $\mathrm{x}$ & & \\
\hline $72 R 02$ & 703.4 & $\begin{array}{l}\text { Fine- to medium-grained ( } 1 \mathrm{~mm}) \text {, intergranular, } \\
\text { aphyric texture; plagioclase (An73) is } \\
\text { fractured and slightly sericitized; dark } \\
\text { interstitial areas. }\end{array}$ & $x$ & $\mathrm{x}$ & $x$ & $x$ & $\mathrm{x}$ \\
\hline $72 \mathrm{R} 03$ & 704.6 & $\begin{array}{l}\text { Medium-grained (1.5 mm), aphyric; } \\
\text { intergranular to subophitic texture; dark } \\
\text { interstitial areas; plagioclase (An78). }\end{array}$ & $x$ & $\mathrm{x}$ & $\mathrm{x}$ & & \\
\hline $72 R 04$ & 706.1 & $\begin{array}{l}\text { Medium-grained ( } 2 \mathrm{~mm}) \text {, slightly porphyritic } \\
\text { with anhedral phenocrysts of } \\
\text { clinopyroxene, some plagioclase enclosed } \\
\text { in clinopyroxene; intergranular; inclusions } \\
\text { of finer-grained, holocrystalline material; } \\
\text { dark interstitial areas. }\end{array}$ & $\mathrm{x}$ & $\mathrm{x}$ & $\mathrm{x}$ & $\mathrm{x}$ & $\mathrm{x}$ \\
\hline 73R01 & 707.2 & $\begin{array}{l}\text { Medium-grained, slightly plagioclase (An63) } \\
\text { porphyritic; plagioclase fractured and } \\
\text { sericitized; intergranular texture; altered } \\
\text { interstitial patches extensive; also } \\
\text { interstitial myrmekitic intergrowths. }\end{array}$ & $\mathrm{x}$ & & & & \\
\hline 73R02 & 709.4 & $\begin{array}{l}\text { Medium-grained, weakly clinopyroxene phyric } \\
(1.5 \mathrm{~mm}) \text {; groundmass plagioclase (An78); } \\
\text { intergranular texture; interstitial alteration } \\
\text { and patches of myrmekitic intergrowths. }\end{array}$ & $\mathrm{x}$ & & & & \\
\hline 73R03 & 711.3 & $\begin{array}{l}\text { Medium-grained, clinopyroxene phyric; } \\
\text { euhedral clinopyroxene phenocrysts }(2 \mathrm{~mm}) \\
\text { with plagioclase inclusions; alteration } \\
\text { concentrated in narrow zones and } \\
\text { interstitial areas. }\end{array}$ & $\mathrm{x}$ & $\mathrm{x}$ & $\mathrm{x}$ & $\mathrm{x}$ & $\mathrm{x}$ \\
\hline 73R04 & 712.4 & $\begin{array}{l}\text { Fine- to medium-grained, weakly clinopyroxene } \\
\text { phyric (1-2 mm); plagioclase inclusions in } \\
\text { clinopyroxene phenocrysts; groundmass } \\
\text { plagioclase (An68); intergranular to } \\
\text { subophitic texture; interstitial alteration. }\end{array}$ & $\mathrm{x}$ & $x$ & $\mathrm{x}$ & & \\
\hline 73R05 & 713.4 & $\begin{array}{l}\text { Fine-grained, porphyritic with } \\
\text { microphenocrysts of clinopyroxene ( } 2 \mathrm{~mm}) \text {; } \\
\text { plagioclase (An65); local alteration of } \\
\text { clinopyroxene; interstitial patches of } \\
\text { alteration. }\end{array}$ & & $x$ & $\mathrm{x}$ & & \\
\hline 73R06 & 715.5 & $\begin{array}{l}\text { Fine-grained, intergranular; porphyritic with } \\
\text { microphenocrysts of poikilitic } \\
\text { clinopyroxene ( } 3 \mathrm{~mm} \text { ) and } \\
\text { glomeroporphyritic clusters of } \\
\text { clinopyroxene and plagioclase; poikilitic } \\
\text { inclusions of plagioclase (An76) and } \\
\text { opaques in clinopyroxene phenocrysts; } \\
\text { less-altered interstitial areas; olivine(?) } \\
\text { pseudomorphs. }\end{array}$ & $\mathbf{x}$ & $\mathbf{x}$ & $\mathrm{x}$ & & \\
\hline 74R01 & 719.2 & As 73R06 above; plagioclase (An74). & $\mathrm{x}$ & $\mathrm{x}$ & $\mathrm{x}$ & $\mathrm{x}$ & \\
\hline 74R02 & 721.0 & $\begin{array}{l}\text { As 73R06 above, with addition of subophitic } \\
\text { texture and increase in the number of } \\
\text { olivine(?) pseudomorphs; fractures with } \\
\text { opaques; plagioclase (An68). }\end{array}$ & $\mathrm{x}$ & $\mathrm{x}$ & $\mathrm{x}$ & $\mathrm{x}$ & $\mathbf{x}$ \\
\hline 74R03 & 722.5 & As 74R02 above; plagioclase (An67). & $\mathbf{x}$ & $\mathrm{x}$ & $\mathrm{x}$ & & \\
\hline 74R04 & 724.1 & $\begin{array}{l}\text { As } 74 \mathrm{R} 02 \text { above, with up to } 20 \% \text { olivine(?) } \\
\text { pseudomorphs; plagioclase (An69). }\end{array}$ & $\mathrm{x}$ & $\mathrm{x}$ & $\mathrm{x}$ & & \\
\hline 74R05 & 725.4 & As $74 \mathrm{R} 04$ above; plagioclase (An73). & $\mathrm{x}$ & $\mathrm{x}$ & $\mathrm{x}$ & & \\
\hline 74R06 & 727.8 & As 74R04 above; plagioclase (An71). & $\mathrm{x}$ & & & & \\
\hline 74R07 & 728.9 & As $74 \mathrm{R} 04$ above; plagioclase (An72). & $\mathrm{x}$ & & & & \\
\hline 75R04 & 735.3 & $\begin{array}{l}\text { Finer-grained, aphyric to microporphyritic (1 } \\
\text { mm); submicrophenocrysts of } \\
\text { clinopyroxene with plagioclase inclusions } \\
\text { (An78); olivine (?) pseudomorphs and } \\
\text { interstitial alteration present. }\end{array}$ & $\mathrm{x}$ & $\mathrm{x}$ & $\mathrm{x}$ & $\mathrm{x}$ & $\mathrm{x}$ \\
\hline
\end{tabular}

$\mathrm{E}=$ electron microprobe mineral chemistry (average of core compositions); $\mathrm{M}=$ whole-rock, major-element analysis; XT = whole-rock, trace-element analysis by X-ray fluorescence; NT = whole-rock trace-element analysis by instrumental neutron activation; I = strontium and neodymium isotopes by solid-source mass spectrometry. 
4. Clinopyroxene-Phyric, fine- to medium-grained, intergranular microporphyritic texture with poikilitic microphenocrysts of clinopyroxene and with interstitial patches of highly altered, dark brown material (Cores 105-647A-73R-1 to 105-647A-73R-5) (Pl. 3).

5. Glomeroporphyritic, fine- to medium-grained, intergranular to subophitic texture, with fresh, glomeroporphyritic clusters of clinopyroxene and plagioclase that give a blotchy appearance to the rock, poikilitic microphenocrysts (up to $3 \mathrm{~mm}$ ) of clinopyroxene, and with variable amounts $(10 \%-20 \%)$ of small $(0.5-$ $1 \mathrm{~mm}$ ), completely altered grains having the shape of olivine with dark red-brown to opaque rims, and dark interstitial areas probably representing altered glass (Cores 105-647A-73R-6 to 105-647A-74R-7) (Pl. 4).

6. Aphyric II, finer-grained, aphyric to microporphyritic with poikilitic microphenocrysts of clinopyroxene and the small, darkrimmed pseudomorphs described above (Core 105-647A-75R-4).

In addition, all samples are characterized by $4 \%-10 \%$ opaques that are dominantly titanomagnetite.

There is mineralogical and textural evidence to support the existence of a minimum of four distinct units in the $37-\mathrm{m} \mathrm{sec}$ tion of Hole 647A, assuming that (1) and (2) may be related as a chilled upper margin and interior of a unit, respectively, and that (5) and (6) may similarly be the interior and lower chilled margin, respectively, of one unit. From the phenocryst assemblages, especially in the deeper part of the core, the magmas clearly were saturated in olivine/clinopyroxene/plagioclase at the time of eruption. The glomeroporphyritic patches are holocrystalline and show no signs of development of secondary minerals. The plagioclase and clinopyroxene generally are unaltered or are altered only slightly. Most alteration occurs in the dark interstitial areas that presumably contained glass originally and in the small, unidentified (olivine?) grains characteristic of the lowermost two units. Except for these altered phases, the Hole 647A samples are fresh, and we are confident of the reliability of the geochemical data for petrogenetic interpretation.

\section{Mineral Chemistry}

The compositions of plagioclase and clinopyroxene were determined on a JEOL 733 electron microprobe using standard procedures. The end-member plagioclase compositions are given in Table 1, and the clinopyroxene phenocryst and glomeroporphyritic compositions are plotted in Figure 2 . The pyroxene phenocrysts are augitic in composition, and the discriminant plot (Nisbet and Pearce, 1977) shows that they have a probable ocean-floor basalt (OFB) affinity that is consistent with their apparent tectonic association. Groundmass grains show considerably more scatter in composition, probably as a result of rapid crystallization.

\section{WHOLE-ROCK CHEMISTRY}

\section{Introduction}

Fourteen of the 20 samples were analyzed for major elements and a group of trace elements. A subset of six samples, representing the extremes of variation in the original 14 , was selected for analysis of other trace elements, including the rare earth elements (REEs), and for analysis of strontium and neodymium isotopes. A similar number of representative samples from the BI-WG suite described by Clarke (1970) were also included in this subset. For reasons of analytical interferences and limits on batch size, not every sample in this subset was run for each element.

\section{ANALYTICAL PROCEDURES}

Major elements were determined using fused glass disks in a Philips PW1400 sequential X-ray fluorescence spectrometer equipped with a rhodium tube. Analytical precision is approximately $2 \%$ of the amount present for major elements. Some of the trace elements (barium, rubidium, strontium, yttrium zirconium, zinc, copper, nickel, chromium, and vanadium) were also determined by $\mathrm{X}$-ray fluorescence with analytical precisions generally better than $5 \%$. The remainder of the trace elements (scandium, cesium, hafnium, tantalum, thorium, uranium, and the REEs) were determined by instrumental neutron activation analysis (Gibson and Jagam, 1980), in which the analytical precisions are better than $10 \%$ of the amounts present. Strontium and neodymium isotopic ratios were determined using the procedures outlined by Bell and Blenkinsop (1987). Strontium isotope ratios were normalized to a ${ }^{86} \mathrm{Sr} /{ }^{88} \mathrm{Sr}$ value of 0.1194 , with a $2-\sigma$ precision of \pm 0.00003 for ${ }^{87} \mathrm{Sr} /{ }^{86} \mathrm{Sr}$. Neodymium isotope ratios were normalized to ${ }^{146} \mathrm{Nd} / 144 \mathrm{Nd}$ value if 0.7219 , with a $2-\sigma$ precision of \pm 0.00002 for ${ }^{143} \mathrm{Nd} /{ }^{144} \mathrm{Nd}$.

\section{Major Elements}

The samples analyzed for major elements are given in Table 2. It is evident from these data that all the Hole $647 \mathrm{~A}$ samples are similar in composition and that they are silica-saturated tholeiites with either minor normative olivine or normative quartz. The $\mathrm{MgO}$ contents show little variation (6.94-9.56 wt \%), and the loss on ignition values is generally less than $2 \mathrm{wt} \%$ (mean $1.38 \mathrm{wt} \%$ ). In addition, note that the Hole $647 \mathrm{~A}$ samples are remarkably low in $\mathrm{K}_{2} \mathrm{O}(0.01-0.09 \mathrm{wt} \%)$, a further indication of both the freshness and the primitive, i.e., relatively undifferentiated, nature of these rocks. The other two incompatible elements among the major elements are $\mathrm{Ti}$ and $\mathrm{P}$ (Fig. 3), both of which also have low values and are similar to MORBs (Sun et al., 1979; Pearce, 1983; Castillo et al., 1986), although they are not as depleted as the putative parent of MORBs that was suggested by Elthon and Casey (1985).

With their low values of titanium-potassium-phosphorus, the Hole 647A samples are similar to the Paleocene picritic tholeiites from Baffin Island and Svartenhuk, West Greenland (Clarke, 1970). It was for this reason that some of these more northerly rocks of essentially the same age $(58 \pm 2 \mathrm{Ma}$, Clarke and Upton, 1971) were included in the sample subset for REEs and isotopes, described next. All of these samples are shown in several different CMAS projections (Fig. 4) of O'Hara (1968) and Elthon (1983), with the latter using the positions of the pressure-dependent cotectic lines of Elthon and Scarfe (1984). The BI-WG samples extend along a well-defined olivine control line, whereas the Hole $647 \mathrm{~A}$ samples cluster tightly between the 1 -atm and 10-kbar pseudoinvariant points. The Hole 647A samples lie within the olivine primary phase volume at 1 atm and thus should not be in equilibrium with microphenocrysts of clinopyroxene and plagioclase. Among the reasons for the clustering are the possibility that there may only be one flow, contrary to the textural evidence, or if more than one flow, the possibility that these magmas were equilibrated with olivine, clinopyroxene, and plagioclase at some pseudoinvariant point between 1atm and $10 \mathrm{kbar}$. These conditions might correspond to a magma chamber at the base of an evolving oceanic crust, as suggested by numerous geophysical and petrological (based on cumulate sequences in ophiolites) models developed elsewhere.

The major elements were also recast into the $F_{1}, F_{2}$ and $F_{3}$ eigenvectors of Pearce (1976) and are shown in Figure 5. These diagrams confirm an ocean-floor basalt/low-potassium tholeiitic affinity for the Hole 647A rocks and demonstrate similar affinities for the BI-WG samples, although the latter rocks erupted onto Precambrian crust.

\section{Trace Elements}

Trace-element data are also shown in Table 2. Elements selected for their petrogenetic or tectonic significance are shown in the following sequence of figures. Some of these plots involve only the subset of samples because one or more necessary elements were not available for all samples. 

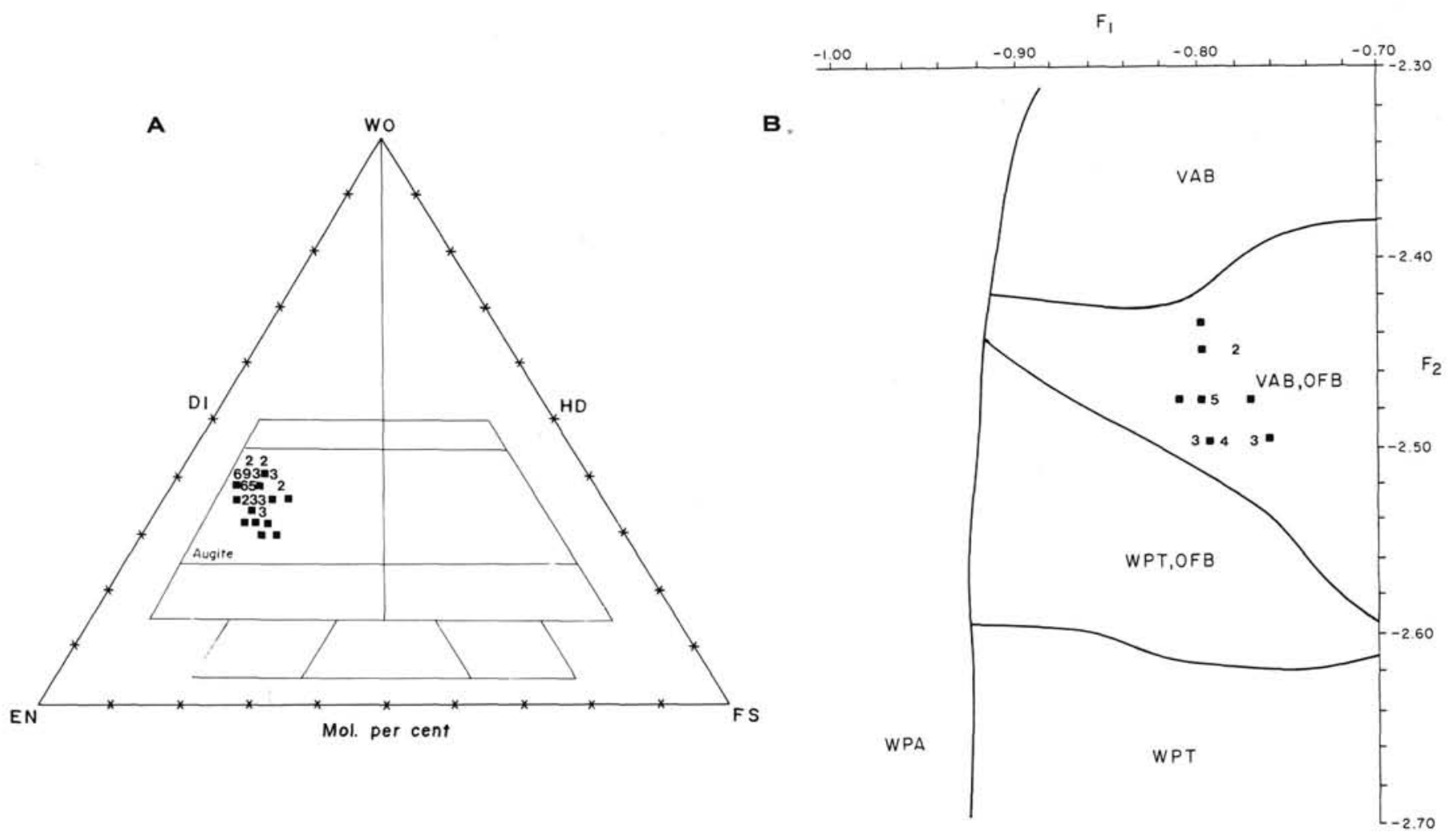

Figure 2. A. Pyroxene quadrilateral showing the compositions of clinopyroxene microphenocrysts and glomeroporphyritic grains only. B. Clinopyroxene discriminant diagram. The Hole $647 \mathrm{~A}$ samples are plotted in the overlap region of within-plate tholeiites $(W P T)$, ocean-floor basalts $(O F B)$, and volcanic-arc basalts $(V A B)$, but do not appear to have the characteristics of within-plate alkali basalts (WPA).

\section{Petrogenetic Diagrams}

Figure 6 shows a plot of magnesium oxide $(\mathrm{MgO})$ and nickel (Ni) in which the Hole 647A samples plot at the evolved (i.e., highly differentiated) end of a fractionation trend defined by the BI-WG samples. This trend includes cumulates at the high$\mathrm{MgO}$ end, primary magmas with about $20 \% \mathrm{MgO}$ (Clarke, 1970; Clarke and O'Hara, 1979), and the products of dominantly olivine removal at the low- $\mathrm{MgO}$ end. The most fractionated WG samples are located within the Hole $647 \mathrm{~A}$ cluster. This trend is probably not distinguishable from other $\mathrm{MgO}-\mathrm{Ni}$ trends for basalts worldwide, and thus restricted petrogenetic significance is attached to these two elements.

Figure 7 shows plots of the geochemically similar, high-fieldstrength incompatible elements, titanium-zirconium-hafnium. The Hole 647A and BI-WG samples evolve along the same line and overlap to a large degree. In contrast to the $\mathrm{MgO}-\mathrm{Ni}$ plot (Fig. 6), we believe that these elements suggest similar evolutionary processes, including similar ratios in the source regions for the two suites.

Figure 8 shows six $\mathrm{MgO}$-trace-element diagrams based on the assumption that the concentration of $\mathrm{MgO}$ is an inverse measure of the degree of differentiation from a primary magma. The scandium and yttrium concentrations in the Hole $647 \mathrm{~A}$ samples are compatible with these elements being members of the BI-WG evolutionary sequence, but hafnium-zirconium-tantalum, and SumREEs are all depleted in the Hole 647A samples at the same degree of differentiation. It is less obvious how the two groups may be genetically related, if at all.

Figure 9 shows some relationships between pairs of incompatible but geochemically dissimilar trace elements. Except for the yttrium/scandium and lanthanum/tantalum plots in which the Hole 647A and BI-WG suite have the same yttrium/scandium and lanthanum/tantalum ratios, all other diagrams indi- cate that only the most primitive BI samples and the Hole $647 \mathrm{~A}$ samples lie on straight lines. In diagrams such as these, olivine control lines are radial through the origin; thus the Hole 647A samples could have evolved from primary magmas (and a source mantle) that were similar. The remainder of the BI-WG suite lies off the radials, which suggests that in addition to the demonstrated importance of olivine fractionation (Figs. 6 and 8), some other process must be involved in their evolution. This process may have been the involvement of another fractionating phase, contamination, or a different mantle source composition. These options are discussed further below.

Figure 10 shows a conventional REE plot in which all the Hole 647A samples are virtually identical, have light-REE-depleted patterns typical of MORBs, and are bracketed by the variation shown by the BI-WG samples. In general, the BI picrites are more primitive than the Hole $647 \mathrm{~A}$ basalts, and the WG basalts are more evolved (see also O'Nions and Clarke, 1972).

Figure 11 is a spidergram normalized vs. the primordial mantle of Wood (1979), except that the Yb normalization value is from Sun and Nesbitt (1977). Once more, the Hole 647A samples are bracketed by the BI-WG samples and both suites show enrichments of generally 1 to 20 times primordial mantle, again underscoring their primitive nature. Either high degrees of partial melting (unlikely because of the relatively low $\mathrm{MgO}$ content), low degrees of fractional crystallization (also unlikely for the same reason), or depleted mantle (most probable) could be responsible for the low incompatible element concentrations in the Hole $647 \mathrm{~A}$ basalts.

\section{Tectono-Magmatic Discrimination Diagrams}

Figure 12 shows the familiar titanium-zirconium-yttrium and titanium-zirconium-strontium plots of Pearce and Cann (1973). In the former, the Hole $647 \mathrm{~A}$ samples are plotted entirely within 
D. B. CLARKE, B. I. CAMERON, G. K. MUECKE, J. L. BATES

Table 2. Chemical analyses of Hole 647A basalts and samples from Davis Strait.

\begin{tabular}{lrrrrrrr}
\hline $\begin{array}{l}\text { Compound/ } \\
\text { element }\end{array}$ & $73 \mathrm{R} 06$ & $74 \mathrm{R} 01$ & $74 \mathrm{R} 02$ & $74 \mathrm{R} 03$ & $74 \mathrm{R} 04$ & 74R05 & 75R04 \\
\hline $\mathrm{SiO}_{2}$ & 49.47 & 49.33 & 50.42 & 50.06 & 48.78 & 49.43 & 49.18 \\
$\mathrm{TiO}_{2}$ & 1.11 & 1.06 & 1.05 & 1.15 & 1.17 & 1.01 & 1.12 \\
$\mathrm{Al}_{2} \mathrm{O}_{3}$ & 13.65 & 14.02 & 13.89 & 13.95 & 13.21 & 13.79 & 13.98 \\
$\mathrm{Fe}_{2} \mathrm{O}_{3}$ & 1.69 & 1.61 & 1.73 & 1.85 & 1.71 & 1.95 & 1.98 \\
$\mathrm{FeO}$ & 9.57 & 9.08 & 9.79 & 10.47 & 9.61 & 11.05 & 11.19 \\
$\mathrm{MnO}$ & 0.18 & 0.18 & 0.23 & 0.33 & 0.21 & 0.19 & 0.24 \\
$\mathrm{MgO}$ & 8.01 & 8.04 & 8.73 & 8.69 & 8.66 & 9.42 & 9.56 \\
$\mathrm{CaO}$ & 11.91 & 11.87 & 12.08 & 11.44 & 11.41 & 11.02 & 10.82 \\
$\mathrm{Na}{ }_{2} \mathrm{O}$ & 2.21 & 1.82 & 2.05 & 2.03 & 1.76 & 2.11 & 1.93 \\
$\mathrm{~K}_{2} \mathrm{O}$ & 0.03 & 0.05 & 0.03 & 0.04 & 0.05 & 0.09 & 0.04 \\
$\mathrm{P}_{2} \mathrm{O}_{5}$ & 0.11 & 0.11 & 0.16 & 0.16 & 0.11 & 0.15 & 0.15 \\
$\mathrm{H}_{2} \mathrm{O}+$ & 0.98 & 1.61 & - & - & 2.04 & - & - \\
$\mathrm{Total}$ & 98.92 & 98.78 & 100.16 & 100.17 & 98.72 & 100.21 & 100.19
\end{tabular}

CIPWNORM

$\begin{array}{lrrrrrrr}\mathrm{Q} & \overline{0} & 1.20 & - & - & 0.64 & \overline{0} & \overline{0} \\ \mathrm{Or} & 0.18 & 0.30 & 0.18 & 0.24 & 0.30 & 0.53 & 0.24 \\ \mathrm{Ab} & 18.70 & 15.40 & 17.35 & 17.18 & 14.89 & 17.85 & 16.33 \\ \mathrm{An} & 27.24 & 29.94 & 28.61 & 28.84 & 28.00 & 27.89 & 29.37 \\ \mathrm{Di} & 25.50 & 23.08 & 24.76 & 22.04 & 22.79 & 21.14 & 19.11 \\ \mathrm{Hy} & 19.85 & 22.65 & 23.12 & 25.05 & 25.11 & 20.21 & 23.97 \\ \text { Ol } & 1.66 & - & 1.27 & 1.60 & - & 7.50 & 5.83 \\ \mathrm{Mt} & 2.45 & 2.33 & 2.51 & 2.68 & 2.48 & 2.83 & 2.87 \\ \text { Il } & 2.11 & 2.01 & 1.99 & 2.18 & 2.22 & 1.92 & 2.13 \\ \mathrm{Ap} & 0.25 & 0.25 & 0.37 & 0.37 & 0.25 & 0.35 & 0.35\end{array}$

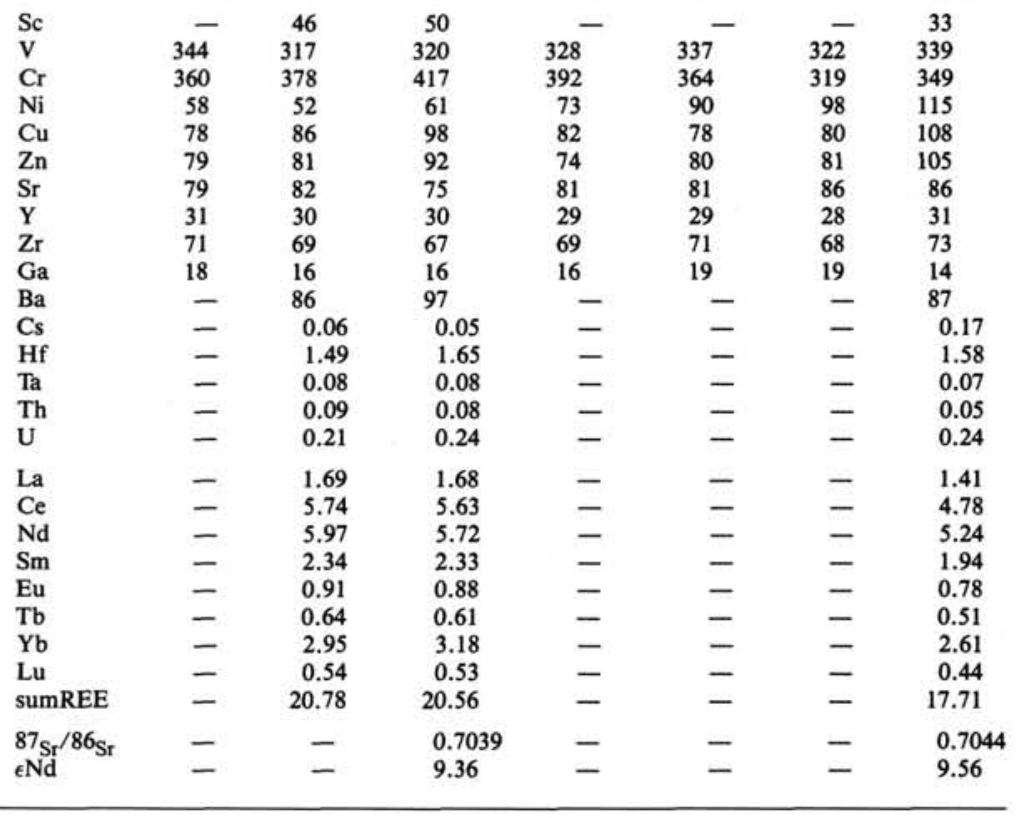

\begin{tabular}{lrrrrrrr}
\hline $\begin{array}{l}\text { Compound/ } \\
\text { element }\end{array}$ & 72R01 & 72R02 & 72R03 & 72R04 & $73 R 03$ & $73 R 04$ & $73 R 05$ \\
\hline $\mathrm{Sc}$ & - & 49 & - & 48 & 42 & - & - \\
$\mathrm{V}$ & 402 & 396 & 429 & 394 & 357 & 344 & 368 \\
$\mathrm{Cr}$ & 196 & 211 & 209 & 188 & 230 & 233 & 249 \\
$\mathrm{Ni}$ & 36 & 44 & 44 & 40 & 39 & 47 & 45 \\
$\mathrm{Cu}$ & 86 & 122 & 101 & 124 & 138 & 109 & 103 \\
$\mathrm{Zn}$ & 80 & 98 & 90 & 92 & 80 & 77 & 84 \\
$\mathrm{Sr}$ & 84 & 82 & 80 & 89 & 82 & 79 & 77 \\
$\mathrm{Y}$ & 33 & 32 & 33 & 36 & 30 & 31 & 31 \\
$\mathrm{Zr}$ & 79 & 78 & 81 & 80 & 64 & 74 & 74 \\
$\mathrm{Ga}$ & 17 & 19 & 19 & 17 & 14 & 15 & 17 \\
$\mathrm{Ba}$ & - & 92 & - & 106 & 96 & - & - \\
$\mathrm{Cs}$ & - & 0.06 & - & 0.05 & 0.05 & - & - \\
$\mathrm{Hf}$ & - & 2.18 & - & 2.07 & 1.61 & - & - \\
$\mathrm{Ta}$ & - & 0.11 & - & 0.11 & 0.07 & - & - \\
$\mathrm{Th}$ & - & 0.14 & - & 0.07 & 0.08 & - & - \\
$\mathrm{U}$ & - & 0.29 & - & 0.19 & 0.15 & - & - \\
$\mathrm{La}$ & - & 2.09 & - & 1.95 & 1.81 & - & - \\
\hline
\end{tabular}


Table 2 (continued).

\begin{tabular}{|c|c|c|c|c|c|c|c|}
\hline $\begin{array}{l}\text { Compound/ } \\
\text { element }\end{array}$ & 72R01 & 72R02 & $72 R 03$ & $\begin{array}{c}\text { Sample } \\
\text { 72R04 }\end{array}$ & $73 R 03$ & $73 R 04$ & 73R05 \\
\hline $\mathrm{Ce}$ & - & 7.09 & - & 6.45 & 5.33 & - & - \\
\hline Nd & - & 7.52 & - & 7.28 & 6.05 & - & - \\
\hline $\mathrm{Sm}$ & - & 2.93 & - & 2.78 & 2.23 & - & - \\
\hline $\mathrm{Eu}$ & - & 1.06 & - & 1.11 & 0.88 & - & - \\
\hline $\mathrm{Tb}$ & - & 0.73 & - & 0.64 & 0.58 & - & - \\
\hline $\mathrm{Yb}$ & - & 3.68 & - & 3.58 & 2.88 & - & - \\
\hline $\mathrm{Lu}$ & - & 0.65 & - & 0.62 & 0.48 & - & - \\
\hline sumREE & - & 25.75 & - & 24.41 & 20.24 & - & - \\
\hline${ }^{87}{ }_{\mathrm{Sr}} / 86_{\mathrm{Sr}}$ & - & 0.7041 & - & 0.7039 & 0.7039 & - & - \\
\hline$\epsilon \mathrm{Nd}$ & - & 9.17 & - & 9.17 & 9.36 & - & - \\
\hline \multirow{2}{*}{$\begin{array}{l}\text { Compound/ } \\
\text { element }\end{array}$} & \multicolumn{6}{|c|}{ Sample } & \\
\hline & ВCB02 & ВCB12 & BCB27 & BCS18 & BCS 33 & & \\
\hline $\mathrm{Sc}$ & 26 & 30 & 40 & 33 & 41 & & \\
\hline V & 171 & 221 & 279 & 299 & 370 & & \\
\hline $\mathrm{Cr}$ & 2696 & 1939 & 796 & 1181 & 147 & & \\
\hline $\mathrm{Ni}$ & 1466 & 950 & 340 & 582 & 80 & & \\
\hline $\mathrm{Cu}$ & 64 & 99 & 125 & 127 & 202 & & \\
\hline $\mathrm{Zn}$ & 79 & 80 & 79 & 85 & 102 & & \\
\hline $\mathrm{Sr}$ & 56 & 81 & 139 & 174 & 205 & & \\
\hline $\mathbf{Y}$ & 13 & 16 & 21 & 22 & 34 & & \\
\hline $\mathrm{Zr}$ & 29 & 39 & 69 & 75 & 132 & & \\
\hline $\mathrm{Ga}$ & 12 & 12 & 16 & 16 & 22 & & \\
\hline $\mathrm{Ba}$ & 48 & 58 & 104 & 99 & 179 & & \\
\hline $\mathrm{Cs}$ & 0.04 & 0.12 & 0.16 & 0.11 & 0.07 & & \\
\hline Hf & 0.79 & 0.87 & 1.48 & 1.94 & 3.14 & & \\
\hline Ta & 0.05 & 0.06 & 0.29 & 0.31 & 0.51 & & \\
\hline Th & 0.01 & 0.05 & 0.26 & 0.21 & 0.95 & & \\
\hline $\mathrm{U}$ & 0.14 & 0.23 & 0.25 & 0.27 & 0.44 & & \\
\hline $\mathrm{La}$ & 1.03 & 1.46 & 4.64 & 4.78 & 9.42 & & \\
\hline $\mathrm{Ce}$ & 3.05 & 3.93 & 11.21 & 12.31 & 22.11 & & \\
\hline Nd & 2.63 & 3.61 & 8.12 & 9.66 & 16.49 & & \\
\hline $\mathrm{Sm}$ & 0.99 & 1.27 & 2.27 & 2.78 & 4.76 & & \\
\hline Eu & 0.42 & 0.53 & 0.89 & 1.05 & 1.69 & & \\
\hline $\mathrm{Tb}$ & 0.27 & 0.32 & 0.49 & 0.52 & 0.91 & & \\
\hline $\mathrm{Yb}$ & 1.12 & 1.29 & 1.88 & 1.81 & 3.33 & & \\
\hline Lu & 0.18 & 0.21 & 0.31 & 0.28 & 0.51 & & \\
\hline sumREE & 9.69 & 12.62 & 29.81 & 33.19 & 59.22 & & \\
\hline${ }^{87} \mathrm{Sr}_{\mathrm{r}} / 86_{\mathrm{Sr}}$ & 0.7031 & 一 & 0.7033 & 0.7033 & 0.7034 & & \\
\hline$\in \mathrm{Nd}$ & 8.97 & - & 6.44 & 7.61 & 6.83 & & \\
\hline $\mathrm{SiO}_{2}$ & 49.51 & 44.99 & 47.01 & 46.52 & 47.81 & & \\
\hline $\mathrm{TiO}_{2}$ & 0.52 & 0.71 & 1.08 & 1.29 & 2.24 & & \\
\hline $\mathrm{Al}_{2} \mathrm{O}_{3}$ & 7.71 & 10.01 & 13.71 & 11.39 & 13.89 & & \\
\hline $\mathrm{Fe}_{2} \mathrm{O}_{3}$ & 1.63 & 1.58 & 1.49 & 1.68 & 1.91 & & \\
\hline $\mathrm{FeO}$ & 9.21 & 8.96 & 8.44 & 9.49 & 10.79 & & \\
\hline $\mathrm{MnO}$ & 0.19 & 0.17 & 0.16 & 0.17 & 0.21 & & \\
\hline $\mathrm{MgO}$ & 28.31 & 21.51 & 12.49 & 15.61 & 5.31 & & \\
\hline $\mathrm{CaO}$ & 6.51 & 9.41 & 12.31 & 10.89 & 11.39 & & \\
\hline $\mathrm{Na}_{2} \mathrm{O}$ & 0.85 & 1.11 & 1.67 & 1.62 & 2.42 & & \\
\hline $\mathrm{K}_{2} \mathrm{O}$ & 0.06 & 0.03 & 0.06 & 0.11 & 0.21 & & \\
\hline $\mathrm{P}_{2} \mathrm{O}_{5}$ & 0.06 & 0.09 & 0.12 & 0.14 & 0.23 & & \\
\hline $\mathrm{H}_{2} \mathrm{O}+$ & 0.81 & 0.64 & 1.07 & 0.85 & 3.48 & & \\
\hline Total & 100.37 & 99.21 & 99.61 & 99.76 & 99.89 & & \\
\hline \multicolumn{8}{|l|}{ CIPWNORM } \\
\hline Q & - & - & - & - & 0.63 & & \\
\hline Or & 0.35 & 0.18 & 0.35 & 0.65 & 1.24 & & \\
\hline $\mathrm{Ab}$ & 7.19 & 9.39 & 14.13 & 13.71 & 20.48 & & \\
\hline An & 17.05 & 22.24 & 29.74 & 23.48 & 26.42 & & \\
\hline Di & 11.80 & 19.02 & 24.61 & 23.80 & 23.75 & & \\
\hline $\mathrm{Hy}$ & 9.19 & 6.33 & 7.56 & 7.36 & 16.34 & & \\
\hline $\mathrm{OI}$ & 50.49 & 37.55 & 17.66 & 24.70 & - & & \\
\hline Mt & 2.36 & 2.29 & 2.16 & 2.44 & 2.77 & & \\
\hline II & 0.99 & 1.35 & 2.05 & 2.45 & 4.25 & & \\
\hline Ap & 0.14 & 0.21 & 0.28 & 0.32 & 0.53 & & \\
\hline
\end{tabular}

the overlapping field of island-arc basalts, ocean-floor basalts, and calc-alkali basalts. The BI samples also occupy this field; however, the WG rocks migrate into the within-plate field as the volcanic pile thickens (Clarke, 1977). In the titanium-zirconiumstrontium plot, the Hole $647 \mathrm{~A}$ rocks are designated as oceanic, and the BI-WG group is transitional toward within-plate. Note also from this diagram (and Table 2) that the Hole 647A samples show little variation in strontium contents, suggesting little interaction with seawater. On the other hand, the BI-WG samples show relative enrichments in strontium over the immobile 


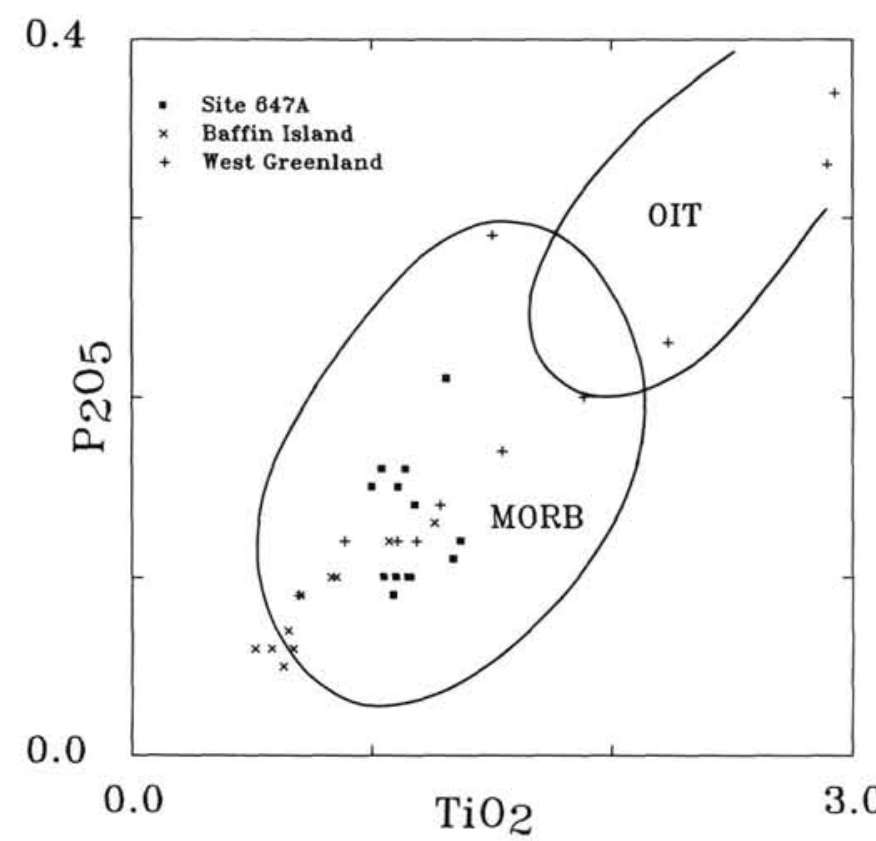

Figure 3. $\mathrm{TiO}_{2}-\mathrm{P}_{2} \mathrm{O}_{5}$ plot showing the MORB-type affinities of the Baffin Island, West Greenland, and Hole $647 \mathrm{~A}$ samples. The more evolved WG rocks, from the top of the volcanic pile, have compositions resembling those of oceanic island tholeiites or within-plate tholeiites.

elements titanium and zirconium, some of which can be related to palagonitization of subaqueous breccias. This point is discussed again in the section on isotopes.

Figure 13 is the titanium-hafnium-tantalum diagram of Wood (1980). As shown in other diagrams, the Hole 647A and BI samples are plotted as N-type MORBs, and the WG samples evolve into related fields, in this case that of tholeiitic within-plate basalts and other differentiates.

\section{Strontium and Neodymium Isotopes}

Previous isotopic work on the BI-WG suite was performed by O'Nions and Clarke (1972), who reported an average of ${ }^{87} \mathrm{Sr} /$ ${ }^{86} \mathrm{Sr}=0.7030$ for nine samples from $\mathrm{BI}$ and ${ }^{87} \mathrm{Sr} /{ }^{86} \mathrm{Sr}=0.7034$ for eight samples from WG, and by Carter et al. (1979), who slightly revised these strontium values and added neodymium isotopic ratios for these rocks. As part of this study, additional BI-WG samples were analyzed for both strontium and neodymium isotopes, together with a representative group from the Hole $647 \mathrm{~A}$ suite. An $\epsilon \mathrm{Nd}-{ }^{87} \mathrm{Sr} /{ }^{86} \mathrm{Sr}$ diagram incorporating the results of all of these studies is shown in Figure 14. Both the BI-WG and Hole 647A suites of samples are depleted in neodymium $(\epsilon \mathrm{Nd}=+2.54$ to +9.56$)$ and ${ }^{87} \mathrm{Sr} /{ }^{86} \mathrm{Sr}(0.7030$ to 0.7041$)$ relative to bulk earth $\left(\epsilon \mathrm{Nd}=0\right.$ and $\left.{ }^{87} \mathrm{Sr} /{ }^{86} \mathrm{Sr}=0.7047\right)$. (In these depleted rocks, present-day values of ${ }^{87} \mathrm{Sr} /{ }^{86} \mathrm{Sr}$ and ${ }^{143} \mathrm{Nd} /{ }^{144} \mathrm{Nd}$ in the basaltic rocks would be indistinguishable from the agecorrected values.) The variation shown by BI-WG samples is a good approximation to the Modern Mantle Trend (Hawkesworth et al., 1983) and implies significant differences in the degree of source-mantle depletion to effect these differences. In contrast, the Hole 647A samples show no covariation of the two isotopic systems. There is a very restricted range of $\epsilon \mathrm{Nd}$ but considerable variation in the ${ }^{87} \mathrm{Sr} / 86 \mathrm{Sr}$ isotopic ratio. We consider three possible explanations of the high-strontium isotopic ratios in the Hole 647A samples:

1. Unique Mantle Source. These rocks might reflect a unique mantle composition, but extensive compilations by Hart et al.
(1986) suggest that these rocks are so far removed from the wellestablished $\mathrm{Sr}-\mathrm{Nd}$ isotopic covariation trend that they are unlikely to represent a newly discovered mantle signature.

2. Continental Contamination. These samples may possibly reflect contamination with foundered continental crust, of the kind proposed by Kerr (1967). However, the well-developed magnetic lineations in this part of the Labrador Sea, the high $\epsilon \mathrm{Nd}$, and the lack of any other evidence of reaction with continental crust, (such as an increase in the thorium/ytterbium ratio; all sample plots fall within the MORB/within-plate array as defined by Pearce (1983)) (Fig. 15) suggest that contamination is not the required process, unless selective contamination of ${ }^{87} \mathrm{Sr}$ occurred. Moorbath and Thompson (1980) and Springer et al. (1983) discussed several mechanisms whereby selective diffusion of radiogenic ${ }^{87} \mathrm{Sr}$ might take place.

3. Reaction with Seawater. The strontium isotope anomaly may be the result of reaction with seawater. However, the rather pristine nature of these rocks, coupled with their very low incompatible element contents, particularly $\mathrm{K}, \mathrm{Cs}, \mathrm{La}, \mathrm{U}$, and $\mathrm{Th}$, suggests that this may be an unlikely mechanism. If the process to explain the strontium isotopic values is simple mixing of seawater $\left({ }^{87} \mathrm{Sr} /{ }^{86} \mathrm{Sr}=0.7090\right.$ or $\epsilon \mathrm{Sr}=+64$, and $\mathrm{Sr}=7.3 \mathrm{ppm}$ [Piepgras and Wasserburg, 1985]) with MORB (on the mantle array with $\epsilon \mathrm{Sr}=-27$, the same $\epsilon \mathrm{Nd}$ as the Hole 647A material, and $120 \mathrm{ppm}$ of strontium [Pearce, 1983]), then $35 \%$ of seawater is required. Although one can calculate this reaction using mass balance, no mineralogical or textural evidence suggests that this much water interacted with either the basalt magma, perhaps leading to explosive eruption and the development of tuffs, or with the solid rocks showing extensive alteration. We consider instead a rock with 10 modal $\%$ interstitial glass ( $=$ melt composition) holding $10 \%$ of the strontium in the rock. If this rock has ${ }^{87} \mathrm{Sr} /{ }^{86} \mathrm{Sr}$ of 0.7027 , i.e., on the Modern Mantle Trend, and if only the glass doubles in strontium content and reaches isotopic equilibrium with seawater, then

$$
\begin{aligned}
\text { Altered whole rock }= & {[(0.9 \times 0.7027)+(0.2 \times 0.7090)] / } \\
& 1.1=0.7038
\end{aligned}
$$

In this case, the total strontium in the rock rises by $7 \mathrm{ppm}$ and the isotopic ratio increases from 0.7027 to 0.7038 . Our data are too uniform in these two parameters to permit testing of this model, but such changes in both strontium concentrations and isotopic ratios have been clearly documented elsewhere (Dasch et al., 1973; Staudigel et al., 1980). Acid leaching experiments will have to be performed to confirm that this is indeed the process responsible for the displacement of the the Hole 647A samples off the Modern Mantle Trend.

\section{DISCUSSION}

\section{Number of Cooling Units at Hole 647A}

We concluded from petrographic observations that at least four textural units were represented in the sample suite. In a further attempt to determine the number of flow units represented by these samples, we plotted chemical composition vs. depth (Fig. 16). Several features are apparent from these diagrams, as follows.

1. $\mathrm{MgO}$ and $\mathrm{Ni}$ generally increase with depth, indicating that the uppermost part of the core is more evolved. There may be just two chemical units here, with the break occurring between units 2 and 3 , or between 3 and 4 , as defined in the "Petrology" section (this chapter), although the differences are at the limits of analytical uncertainty. Note that these elements correlate well with the modal abundance of the olivine(?) pseudomorphs, and we regard this correlation as chemical confirma- 


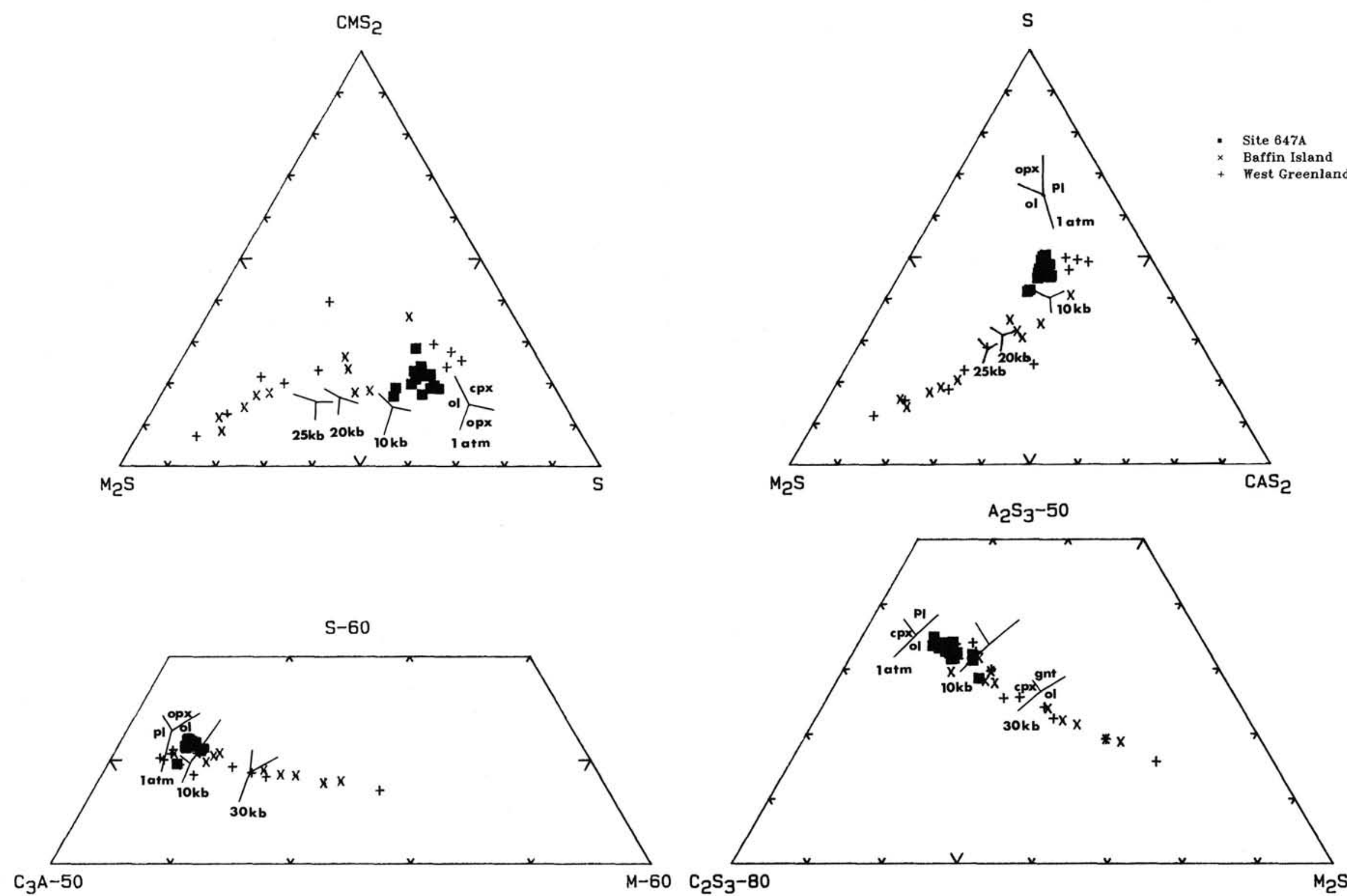

Figure 4. Four CMAS projections showing clustering of the Hole 647A basalts, perhaps at a pseudoinvariant point at a pressure between 1 atm and 10 kbars. The BI-WG samples show variation along an olivine control line. See text for details. 

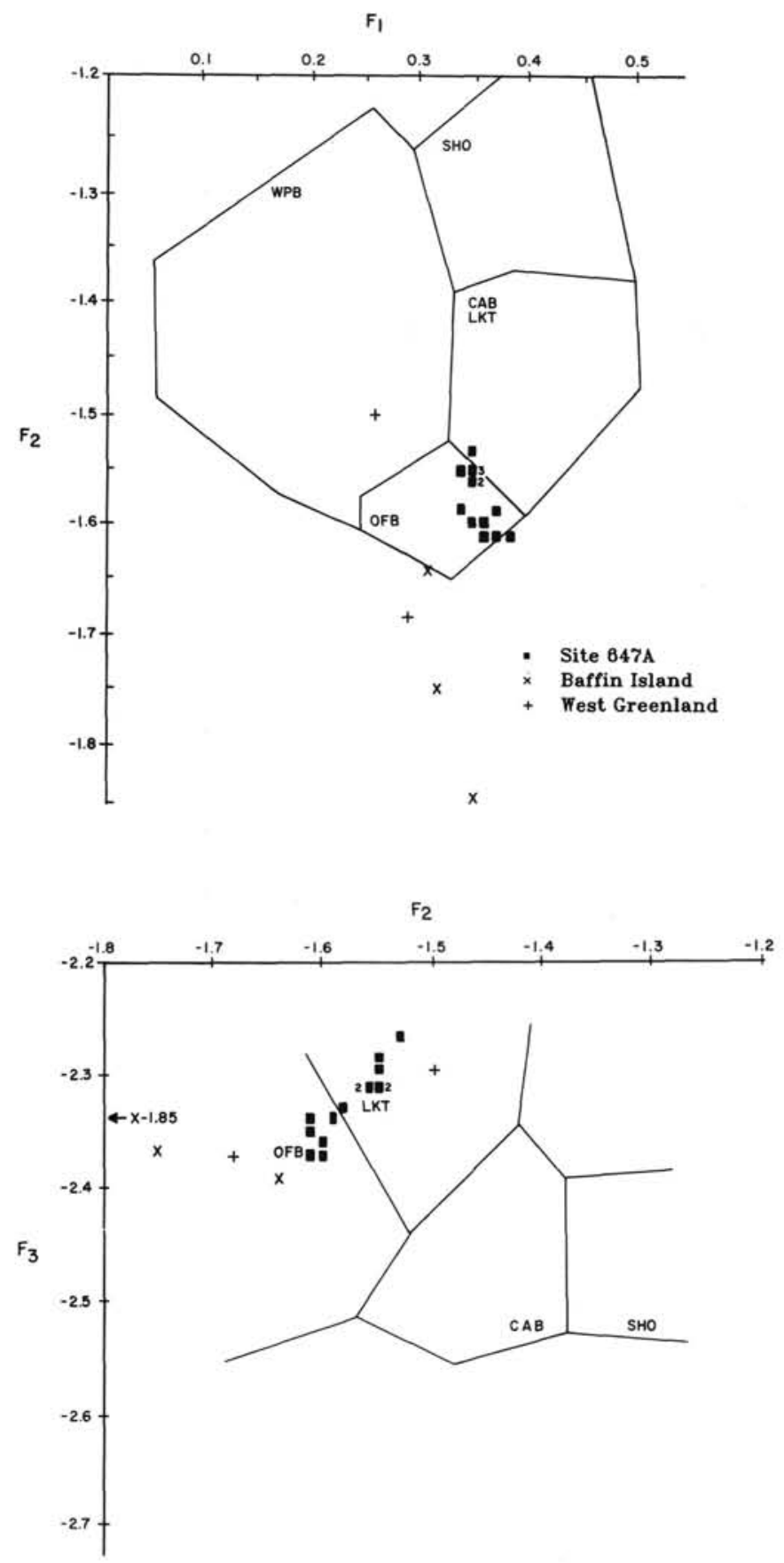

Figure 5. Major-element discriminant diagrams of Pearce (1976). The Hole $647 \mathrm{~A}$ samples are classified as ocean-floor basalts/low-potassium tholeiites.

tion that these phases were originally primary olivine microphenocrysts.

2. Both the zirconium and SumREE contents confirm the more evolved nature of the upper part of the core and suggest a possible break between units 3 and 4 for zirconium, and between 3 and 4 and 5 and 6 for SumREE, although it is possible to interpret both contents in terms of evolution within a single lava flow.

In summary, we do not find sufficient chemical reason to further subdivide the mineralogical/textural division of a minimum of four cooling units $(1+2,3,4$, and $5+6)$. In fact, the chemical data suggest a minimum of only three units $(2+3$, $4+5$, and 6). We stress that these are minima; it is possible to account for both the mineralogical/textural and chemical variations with many more units, perhaps derived from a single evolving magma chamber.

We are not sure whether these cooling units at Hole 647A are flows or sills. Although some seismic evidence for the existence of sills in the vicinity of Hole 647A can be seen, most evidence suggests that the igneous units sampled are flows (uniformly fine grain size, brecciated top of the igneous section, and laminated crust on the top of the igneous unit).

\section{Tectono-Magmatic Discrimination}

In several of the tectonic discriminator diagrams (Figs. 3, 5, 12,13 , and 15), the WG samples showed variation from MORBtype affinities to within-plate affinities. Two interesting aspects concerning this point may be pursued. First, neither the BI nor WG suites (erupted onto Precambrian crust) can be considered MORBs sensu stricto, although they are related to a spreading center (Clarke, 1977). This is a clear example of what may happen as the chemically defined magma-type oversteps its tectonic boundaries in a period of vigorous eruption and serves as a note of caution to those who would use chemical discriminators alone to learn about tectonic affinities. Second, the WG suite is very thick (Clarke and Pedersen, 1976) and shows extensive chemical evolution vertically through the pile from extremely primitive picritic tholeiites to highly differentiated feldspar-phyric tholeiites. Some of the discriminator diagrams record this evolution as a change from MORB toward or into within-plate, although the tectonic environment began as within-plate and evolved to an oceanic-spreading center, respectively. Is it possible that this apparent change in tectonic environment can be attributed solely to simple chemical differentiation or have the mantle source regions changed (e.g., MORB-type vs. OIB-type)? This question is addressed in the next section.

\section{Magma Sources and Evolution of the Labrador Sea and Davis Strait}

Closer inspection of the strontium-neodymtium isotopic variation shown in Figure 14 reveals that there is a suggestion of systematic variation with $\mathrm{MgO}$ content of the lavas in BI and WG. In general, the most primitive lavas (those containing high $\mathrm{MgO}$ ) are those having the most depleted isotopic signatures (Fig. 17). These compositions are strongly related by olivine control lines, but olivine fractionation cannot change the isotopic ratios. We now suggest that the earliest and most picritic lavas in both BI and WG were derived from a mantle long ago depleted not only in rubidium/strontium and neodymium/samarium, but also in large-ion lithophile (LIL) elements such as potassium, lanthanum, etc., and enriched in magnesium/iron. As the Labrador Sea-Baffin Bay spreading center began to operate, this ancient depleted mantle was tapped first to produce the primitive tholeiites, and as deeper and more fertile (richer in basaltic components) mantle ascended and became involved in the melting process, the magmas began to assume a different geochemi$\mathrm{cal}$ character. Thus, two processes are operating here: (1) crystal-liquid fractionation dominated by olivine fractionation occasioned by thickening of the lava pile and running down of the magmatic system (Clarke, 1970; Francis, 1985) and (2) the influence of a more fertile mantle as evidenced by the changing isotopic ratios. Although both isotopic ratios change in the direction of continental crust (higher ${ }^{87} \mathrm{Sr} /{ }^{86} \mathrm{Sr}$ and lower $\epsilon \mathrm{Nd}$ ), it is unlikely that continental material was involved because it would have had to lie on the Modern Mantle Trend and no other evidence of continental contamination exists, e.g., in the thorium/ ytterbium-tautalum/ytterbium diagram (Fig. 15). 


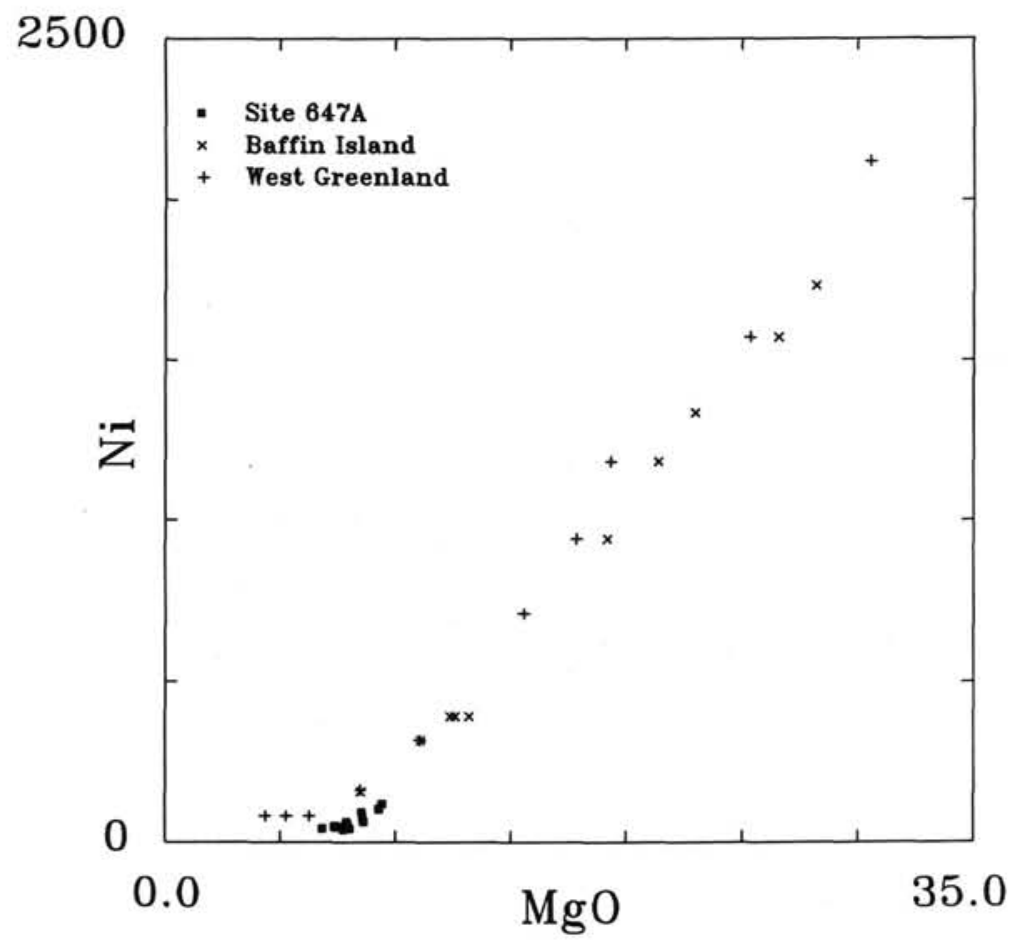

Figure 6. MgO-Ni diagram showing the highly evolved nature of the Hole 647A basalts relative to the BI-WG samples, most of which are picritic tholeites.

In contrast to the similar Davis Strait lavas, the Hole 647A samples appear to have been derived from a much more primitive $N$-type MORB mantle (judging from the high $\epsilon \mathrm{Nd}$ ) typical of other mid-ocean ridge basalts. That depletion may have been related to any one of a number of Archean-Proterozoic igneous events (Table 3) that affected Labrador and southwest Greenland, or perhaps none of them. The small Phanerozoic events are suitable for depleting the mantle in LIL elements, but only the much older events (Gardar or earlier) can have had any effect on the strontium and neodymium isotopic depletion, assuming that the crust and mantle have remained coupled throughout this time. We do not have ${ }^{87} \mathrm{Rb} /{ }^{86} \mathrm{Sr}$ and ${ }^{147} \mathrm{Sm} /{ }^{144} \mathrm{Nd}$ ratios for the Hole 647A rocks and thus are unable to calculate the model ages for the depletion of the source mantle. However, we do know that some of the lavas described here have $\mathrm{Rb} / \mathrm{Sr}$ ratios of 0.002 (O'Nions and Clarke, 1972; Francis, 1985), indicating that the source mantle was even lower. In such a mantle, the growth rate of ${ }^{87} \mathrm{Sr}$ has been very slow since the mid-Proterozoic. Thus, the Labrador Sea volcanic rocks should have approximately the same initial ${ }^{87} \mathrm{Sr} /{ }^{86} \mathrm{Sr}$ ratio as some of the old igneous rocks bordering this small ocean. An unanswered question concerns why the Davis Strait samples have been tapped from more fertile mantle, while the Labrador Sea basalts have not, despite their many similarities.

\section{On Continental Crust in the Labrador Sea}

In view of the former controversy concerning the origin of the Labrador Sea and the consequent petrological nature of its basement, we now examine the geochemical data for any evidence of continental crustal material. Pearce (1983) suggested that high $\mathrm{Ba}$ and high $\mathrm{Th}$ are the most reliable trace-element indicators of crustal contamination of basalts. To these may be added high $\mathrm{K}$, light-REE, $\mathrm{Ta},{ }^{87} \mathrm{Sr}$, and low ${ }^{143} \mathrm{Nd}$, all of which can be features of continental contamination, depending on the type of crust involved. Of these several chemical criteria, the BIWG samples known to have traversed continental crust show none, and the Hole 647A samples display only one, namely, the high strontium isotope ratios. The low $\mathrm{Ba}$ and Th (Figs. 11, 13, and 15) and high $\epsilon$ Nd suggest (Fig. 14) that contamination with continental crust was not a significant process in the evolution of the Labrador Sea basalts. We do not believe that one criterion (high ${ }^{87} \mathrm{Sr} /{ }^{86} \mathrm{Sr}$ ), especially in the light of other possible interpretations previously discussed, constitutes sufficient evidence to make a case for the presence of foundered continental crust in the Labrador Sea. Nevertheless, in view of the absence of a continental crustal signature in the BI-WG suite, the similar lack of geochemical evidence at Hole 647A does not preclude the possibility of foundered continental crust in the Labrador Sea, however unlikely on other grounds.

\section{SUMMARY AND CONCLUSIONS}

The Hole 647A basalts are olivine- to quartz-normative tholeiites equilibrated at low pressures, with low, incompatible element contents. They show typical light-REE-depleted patterns, rather flat spidergrams relative to primordial mantle, and traceelement and mineral chemical discriminators that are compatible with their ocean-floor tectonic setting. They also display MORB-type neodymium isotopic ratios but are strontium isotopic enriched relative to typical MORBs and have many similarities to the BI-WG suite of comparable age in the Davis Strait region. We conclude the following:

1. The Hole 647A and early Baffin Island basalts were derived from similar depleted source mantle composition and both have the chemical characteristics of ocean-floor basalts, $N$-type MORBs, low-potassium tholeiites, and within-plate basalts, etc., appropriate to a spreading center. However, most discriminator diagrams misclassify at least the early members of the BI-WG suite because they have erupted onto continental crust.

2. Later lavas from Baffin Island, and possibly all lavas from West Greenland, were generated from a more enriched 

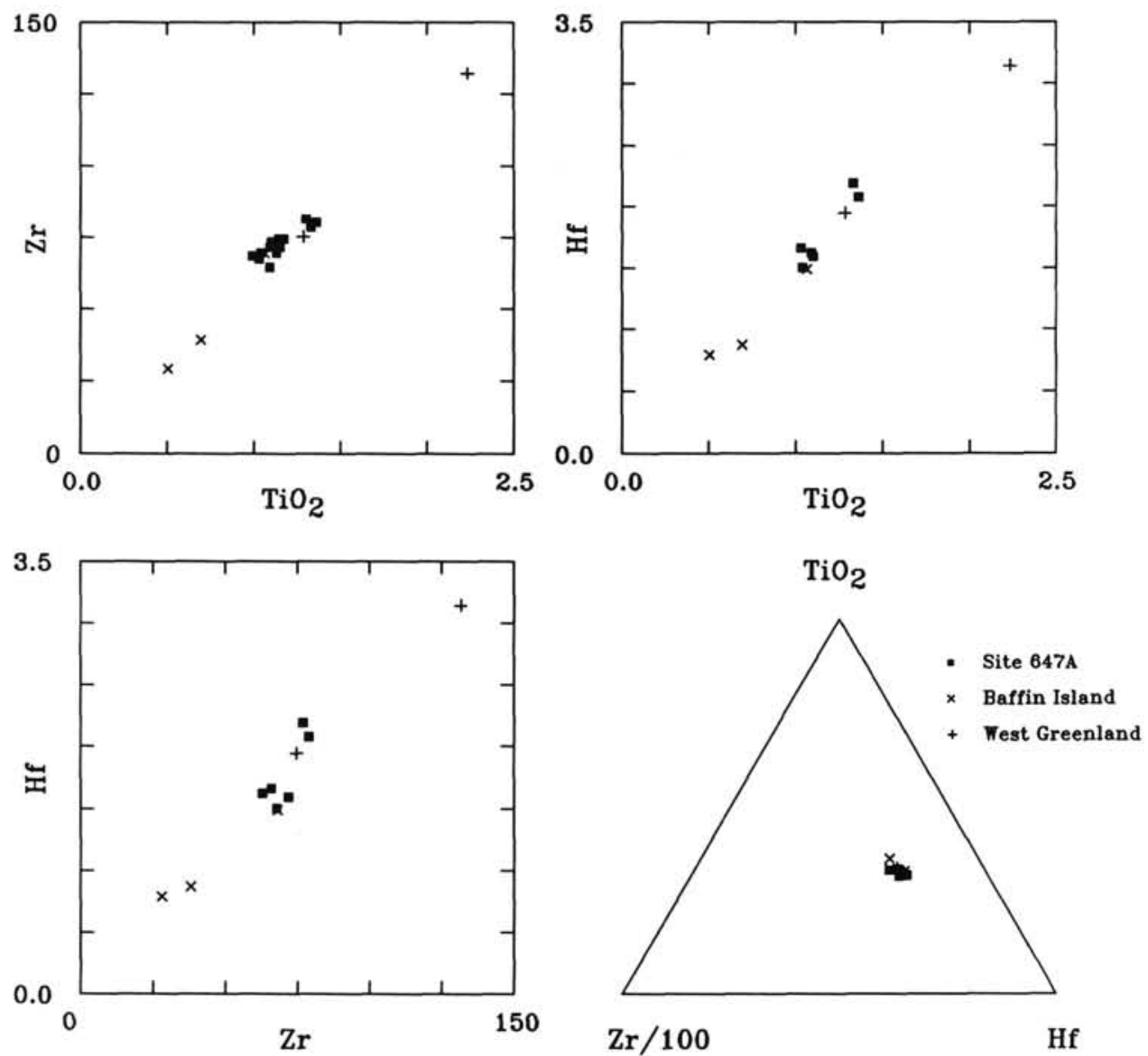

Figure 7. Group IV-A high-field-strength, incompatible and immobile elements showing similar trends and ratios in the BI, WG, and Hole 647A suites. These similar ratios may imply similar source regions and subsequent evolution.

mantle, as indicated by both isotopic and incompatible trace-element compositions.

3. The strontium isotopic composition of Hole $647 \mathrm{~A}$ basalts probably can be attributed to interaction with seawater.

4. There is no geochemical evidence in the Hole $647 \mathrm{~A}$ basalts either for or against the existence of foundered continental crust in Labrador Sea.

\section{ACKNOWLEDGMENTS}

We acknowledge the careful analytical work of P. Jagam (Univ. of Guelph), who determined the rare-earth elements; K. Bell (Carleton Univ.), who provided isotopic data; K. Cameron (Nova Scotia Regional XRF Facility), who provided major- and trace-element analyses; and R. MacKay (Dalhousie Regional Electron Microprobe Laboratory), who assisted with the mineral and whole-rock fusion analyses. We also thank S. Srivastava (Atlantic Geoscience Center) for his enthusiastic support of this project, and J. Dostal for his helpful critique. Finally, D. Clarke and $G$. Muecke gratefully acknowledge financial support from the Natural Sciences and Engineering Research Council of Canada for this research.

\section{REFERENCES}

Allaart, J. H., 1976. Ketilidian mobile belt in south Greenland. In Escher, A., and Watt, W. S. (Eds.), Geology of Greenland. Geol. Surv. Greenland, 120-151.

Ashwal, L., and Wooden, J. L., 1985. Sm-Nd isotopic studies of Proterozoic anorthosites: systematics and implications. In Tobi, A C., and Touret, J. R. (Eds.), The Deep Proterozoic Crust in the North Atlantic Provinces: Dordrecht (D. Reidel Publishing), 61-73.
Ashwal, L. D., Wooden, J. L., and Emslie, R. F., 1986. Speculation on the nature and extent of Archean basement in Labrador as indicated by $\mathrm{Sr}, \mathrm{Nd}$, and $\mathrm{Pb}$ isotopic systematics of Proterozoic intrusives. In Ashwal, L. D. (Ed.), Workshop on Early Crustal Genesis: The World's Oldest Rocks. L.P.I. Tech. Rept. 86-04:17-21.

Barton, J. M., Jr., 1975. The Mugford Group Volcanics of Labrador: age, geochemistry, and tectonic setting. Can. J. Earth Sci., 12:11961208.

Barton, J. M., Jr., and Barton, E. S., 1975. Age and geochemical studies of the Snyder Breccia, coastal Labrador. Can. J. Earth Sci., 12: 361-370.

Bell, K., and Blenkinsop, J., 1987. Archean depleted mantle: evidence from $\mathrm{Nd}$ and $\mathrm{Sr}$ initial isotopic ratios of carbonatites. Geochim. Cosmochim. Acta, 51:291-298.

Bridgwater, D., Keto, L., McGregor, V. R., and Myers, J. S., 1976. Archean Gneiss Complex of Greenland. In Escher, A., and Watt, W. S. (Eds.), The Geology of Greenland, Gronlands Geologiske Undersogelse, 19-75.

Brooks, C., Wardle, R. J., and Rivers, T., 1981. Geology and geochronology of Helikian magmatism, western Labrador. Can. J. Earth Sci., 18:1121-1227.

Carter, S. R., Evensen, N. M., Hamilton, P. J., and O'Nions, R. K., 1979. Basalt magma sources during the opening of the North Atlantic. Nature, 281:28-30.

Castillo, P., Batiza, R., and Stern, R. J., 1986. Petrology and geochemistry of Nauru Basin igneous complex: large-volume off-ridge eruptions of MORB-like basalt during the Cretaceous. In Moberly, R., Schlanger, S. O., et al., Init. Repts. DSDP, 89: Washington (U.S. Govt. Printing Office), 555-576.

Clarke, D.B., 1969. Tertiary basalts of the Baffin Bay area (Ph.D. dissert.). University of Edinburgh. 
Clarke, D. B., 1970. Tertiary basalts of Baffin Bay: possible primary magma from the mantle. Contr. Mineral. Petrol., 25:203-224.

Clarke, D. B., 1977. The Tertiary volcanic province of Baffin Bay. In Baragar, W.R.A., Coleman, L. C., and Hall, J. M. (Eds.), Volcanic Regimes in Canada. Geol. Assoc. Can. Spec. Pap., 16:445-460.

Clarke, D. B., and O'Hara, M. J., 1979. Nickel and the existence of high-MgO liquids in nature. Earth Planet. Sci. Lett., 44:153-158.

Clarke, D. B., and Pedersen, A. K., 1976. Tertiary volcanic province of West Greenland. In Escher, A., and Watt, W. S. (Eds.), Geology of Greenland. Geol. Surv. Greenland, 364-385.

Clarke, D. B., and Upton, B.G.J., 1971. Tertiary basalts of Baffin Island: field relations and tectonic setting. Can. J. Earth Sci., 8:248258.

Collerson, K. D., and McCulloch, M. T., 1982. The origin and evolution of Archaean crust as inferred from $\mathrm{Nd}, \mathrm{Sr}$ and $\mathrm{Pb}$ isotopic studies in Labrador. Trans., Fifth Int. Conf. Geochron., Cosmochron., Isotope Geol., 61-62.

Dasch, E. J., Hedge, C. E., and Dymond, J., 1973. Effect of sea water interaction on isotope composition of deep-sea basalts. Earth Planet. Sci. Lett., 19:177-183.

Elthon, D., 1983. Isomolar and isostructural pseudo-liquidus phase diagrams for oceanic basalts. Am. Mineral., 68:506-511.

Elthon, D., and Casey, J. F., 1985. The very depleted nature of certain primary mid-ocean ridge basalts. Geochim. Cosmochim. Acta, 49: 289-298.

Elthon, D., and Scarfe, C. M., 1984. High-pressure phase equilibria of a high-magnesia basalt and the genesis of primary oceanic basalts. Am. Mineral., 69:1-15.

Emeleus, C. H., and Andrews, J. R., 1975. Mineralogy and petrology of kimberlite dyke and sheet intrusions and included peridotite xenoliths from South-West Greenland. Phys. Chem. Earth, 9:179-197.

Emeleus, C. H., and Upton, B.G.J., 1976. The Gardar Period in southern Greenland. In Escher, A., and Watt, W. S. (Eds.), The Geology of Greenland, Gronlands Geologiske Undersogelse, 153-181.

Emslie, R. F., Loveridge, W. D., and Stevens, R. D., 1984. The Mealy dykes, Labrador: petrology, age, and tectonic significance. Can. J. Earth Sci., 21:437-446.

Francis, D., 1985. The Baffin Bay lavas and the value of picrites as analogues of primary magmas. Contrib. Mineral. Petrol., 89:144-154.

Gibson, I. L., and Jagam, P., 1980. Instrumental neutron activation analysis of rocks and minerals. In Muecke, G. K. (Ed.), Neutron Activation Analysis in the Geosciences. Mineral. Assoc. Can. Sh. Cour. Hdbk., 5:109-131.

Hansen, K., 1980. Lamprophyres and carbonatitic lamprophyres related to rifting in the Labrador Sea. Lithos, 13:145-152.

Hart, S. R., Gerlach, D. C., and White, W. M., 1986. A possible new $\mathrm{Sr}-\mathrm{Nd}-\mathrm{Pb}$ mantle array and consequences for mantle mixing. Geochim. Cosmochim. Acta, 50:1551-1557.

Hawkesworth, C. J., Erlank, A. J., Marsh, J. S., Menzies, M. A., and van Calsteren, P., 1983. Evolution of the continental lithosphere: evidence from volcanics and xenoliths in southern Africa. In Hawkesworth, C. J., and Norry, M. J. (Eds.), Continental Basalts and Mantle Xenoliths: London (Shiva Publishing Ltd.), 111-138.

Hurst, R., Farhat, J., and Wetherill, G., 1977. Very old ( $>3100$ million years) rocks in North America. In Ponnamperuma, C. (Ed.), Chemical Evolution of the Early Precambrian: New York (Academic Press), 25-26.

Johnson, G. L., Srivastava, S. P., Campsie, J., and Rasmussen, M., 1982. Volcanic rocks in the Labrador Sea and environs and their relation to the evolution of the Labrador Sea. Current Research, Part B. Geol. Surv. Can., Pap. 82(1B):7-20.

Kerr, J. W., 1967. A submerged continental remnant beneath the Labrador Sea. Earth Planet. Sci. Lett., 2:283-289.

King, A. F., and McMillan, N. J., 1975. A mid-Mesozoic breccia from the coast of Labrador. Can. J. Earth Sci., 12:44-51.

Larsen, O., and Moller, J., 1968. Potassium-argon age studies in west Greenland. Can. J. Earth Sci., 4:683-691.

Laughton, A. S., Berggren, W. A., Benson, R., Davies, T. A., Franz, U., Musich, L., Perch-Nielsen, K., Ruffman, A., van Hinte, J. E., Whitmarsh, R. B., Aumento, F., Clarke, D. B., Cann, J. R., Ryall, P.J.C., and Burckle, L. H., 1972. Site 112. In Laughton, A. S., Berggren, W. A., et al., Init. Repts DSDP, 12: Washington (U.S. Govt. Printing Office), 161-253.
Leech, G. B., Lowden, J. A., Stockwell, C. H., and Wanless, R. K., 1963. Age determinations and geologic studies. Geol. Surv. Can., Pap. 63(17):116-117.

LePichon, X., Hyndman, R., and Pautot, G., 1971. Geophysical study of the opening of the Labrador Sea. J. Geophys. Res., 76:4724-4743.

Meyerhoff, A. A., 1973. Origin of Arctic and North Atlantic Oceans. In Pritcher, M. G. (Ed.), Arctic Geology. AAPG Mem. 19:562-582.

Moorbath, S., and Thompson, R. N., 1980. Strontium isotope geochemistry and petrogenesis of the early Tertiary lava pile of the Isle of Skye, Scotland, and other basic rocks of the British Tertiary Province: an example of magma-crust interaction. J. Petrol., 21:295-321.

Moorbath, S., O'Nions, R. K., and Pankhurst, R. J., 1975. The evolution of the Precambrian crustal rocks at Isua, West Greenland: geochemical and isotopic evidence. Earth Planet. Sci. Lett., 27:229239.

Morgan, W. C., 1978. Ramah Group volcanics-Labrador. In Wanless, R. K., and Loveridge, W. D. (Eds.), Geol. Survey Can. Pap. 77(14): 56-61.

Nisbet, E. G., and Pearce, J. A., 1977. Clinopyroxene composition in mafic lavas from different tectonic settings. Contrib. Mineral. Petrol., 63:149-160.

O'Hara, M. J., 1968. The bearing of phase equilibria studies in synthetic and natural systems on the origin and evolution of basic and ultrabasic rocks. Earth Sci. Rev., 4:69-133.

O'Nions, R. K., and Clarke, D. B., 1972. Comparative trace element geochemistry of Tertiary basalts from Baffin Bay. Earth Planet. Sci. Lett., 15:436-446.

Pearce, J. A., 1976. Statistical analysis of major element patterns in basalts. J. Petrol., 17:15-43.

Pearce, J. A., 1983. Role of the sub-continental lithosphere in magma genesis at active continental margins. In Hawkesworth, C. J., and Norry, M. J. (Eds.), Continental Basalts and Mantle Xenoliths: (Shiva Publishing Ltd.), 230-249.

Pearce, J. A., and Cann, J. R., 1973. Tectonic setting of basic volcanic rocks determined using trace element analysis. Earth Planet. Sci. Lett., 19:290-300.

Piepgras, D. J., and Wasserburg, G. J., 1985. Strontium and neodymium isotopes in hot springs on the East Pacific Rise and Guajmas Basin. Earth Planet. Sci. Lett., 72:341-356.

Royden, L., and Keen, C. E., 1980. Rifting process and thermal evolution of the continental margin of eastern Canada determined from subsidence curves. Earth Planet. Sci. Lett., 51:343-361.

Springer, N., Pedersen, S., Bridgwater, D., and Glassley, W. E., 1983. One dimensional diffusion of radiogenic ${ }^{87} \mathrm{Sr}$ and fluid transport of volatile elements across the margin of a metamorphosed Archean basic dyke from Saglek, Labrador. Contrib. Mineral. Petrol., 82:2633.

Srivastava, S. P., 1986. Geophysical Maps and Geological Sections of the Labrador Sea. Geol. Surv. Can., Pap. 85(16), 1-11.

Srivastava, S. P., Arthur, M., et al., 1987. Proc. ODP, Init. Repts, 105: College Station, TX (Ocean Drilling Program), 1099-1560.

Srivastava, S. P., Falconer, R.K.H., and MacLean, B., 1981. Labrador Sea, Davis Strait, Baffin Bay: geology and geophysics-a review. In Kerr, J. Wm., and Fergusson, A. J. (Eds.), Geology of the North Atlantic Borderlands, Can. Soc. Pet. Geol., Mem. 7:333-398.

Staudigel, H., Frey, F. A., and Hart, S. R., 1980. Incompatible trace-element geochemistry and ${ }^{87} / 86 \mathrm{Sr}$ in basalts and corresponding glasses and palagonites. In Donnelly, T., Francheteau, J., Bryan, W., Robinson, P., Flower, M., Salisbury, M., et al., Init. Repts. DSDP, 51, 52, 53 (Pt. 1): Washington (U.S. Govt. Printing Office), 1137-1144.

Suess, E., 1906. The Face of the Earth, Vol. II: London (Oxford Press).

Sun, S. S., and Nesbitt, R. W., 1977. Geochemical heterogeneity in the Archaean mantle, composition of the Earth and mantle evolution. Earth Planet. Sci. Lett., 35:429-448.

Sun, S. S., Nesbitt, R. W., and Sharaskin, A., 1979. Geochemical characteristics of mid-ocean ridge basalts. Earth Planet. Sci. Lett., 44: 119-138.

Taylor, F. C., 1979. Reconnaissance geology of a part of the Precambrian Shield, northeastern Quebec, northern Labrador and Northwest Territories. Geol. Surv. Can., Mem. 393, 1-79.

Upton, B.G.J., Stephenson, D., and Martin, A. R., 1985. The Tugtutoq older giant dyke complex: mineralogy and geochemistry of an alkali 
gabbro-augite-syenite-foyaite association in the Gardar Province of South Greenland. Mineral., 49:623-642.

Vogt, P. R., and Avery, O. E., 1974. Detailed magnetic surveys in the northeast Atlantic and Labrador Sea. J. Geophys. Res., 79:363-389.

Wegener, A., 1924. The Origin of Continents and Oceans: London (Methuen).

Wood, D. A., 1979. A variably veined suboceanic upper mantle-genetic significance for mid-ocean ridge basalts from geochemical evidence. Geology, 7:499-503.

Wood, D. A., 1980. The application of a Th-Hf-Ta diagram to problems of tectonomagmatic classification and to establishing the na-
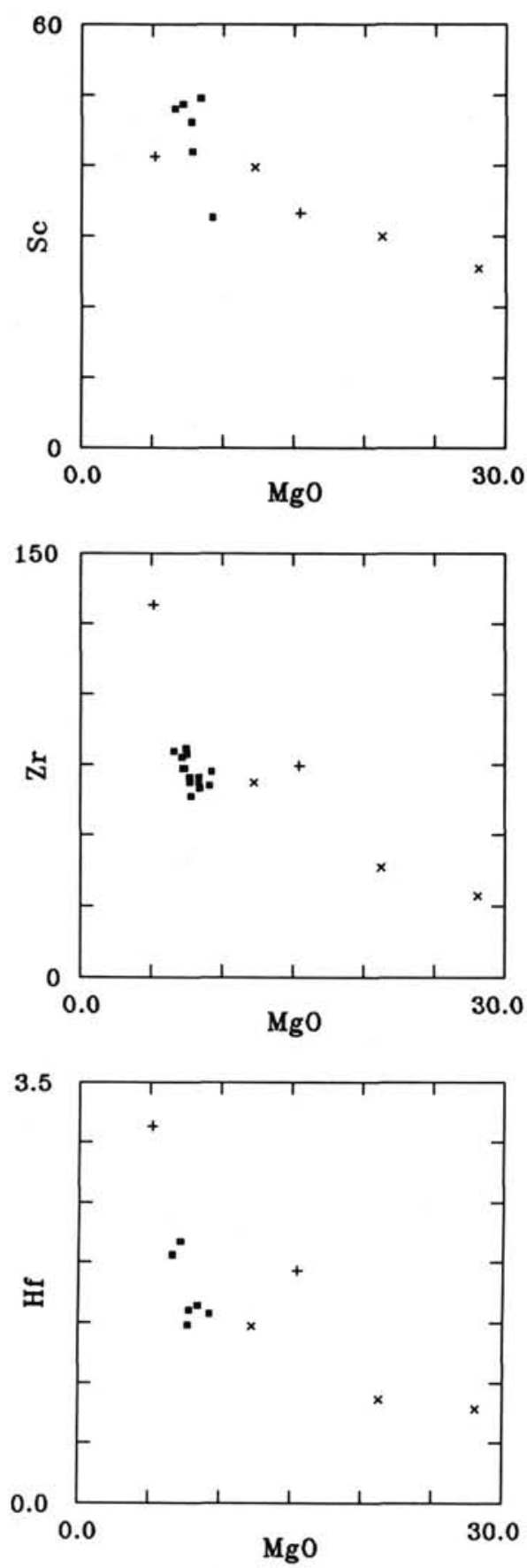

ture of crustal contamination of basaltic lavas of the British Tertiary volcanic province. Earth Planet. Sci. Lett., 50:11-30.

Zindler, A., Hart, S. R., and Brooks, C., 1981. The Shabogomo intrusive suite, Labrador: $\mathrm{Sr}$ and $\mathrm{Nd}$ isotopic evidence for contaminated mafic magmas in the Proterozoic. Earth Planet. Sci. Lett., 54:217235 .

Date of initial receipt: 24 August 1987

Date of acceptance: 16 December 1987

Ms 105B-175
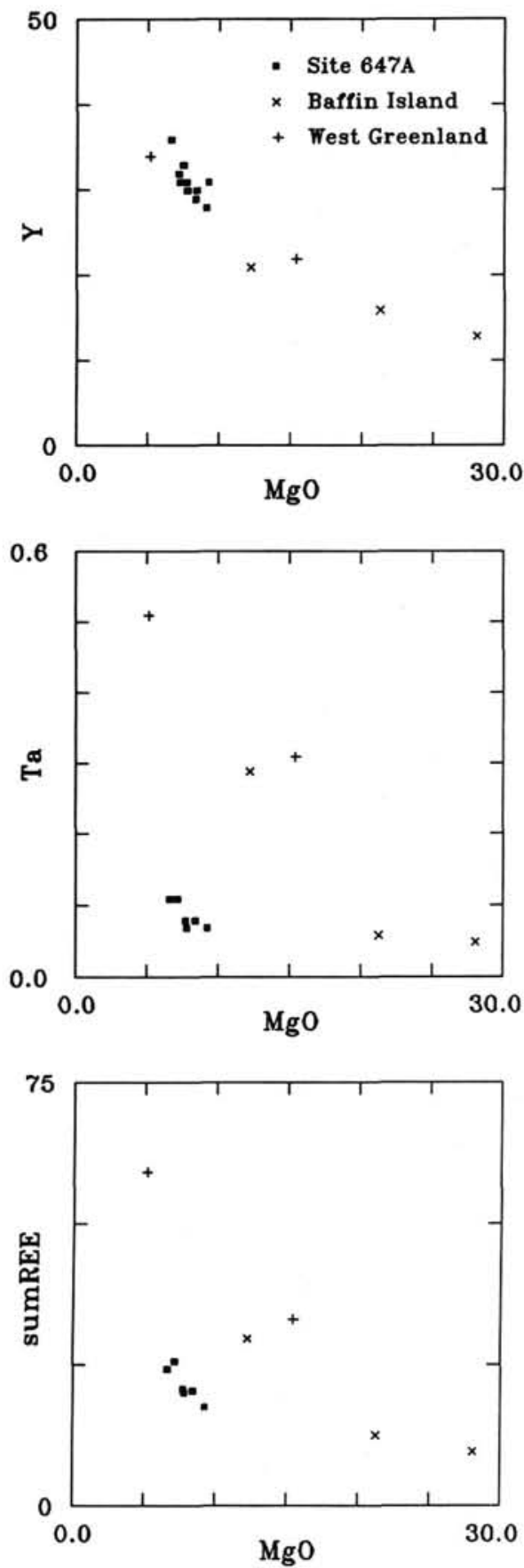

Figure 8. $\mathrm{MgO}$-trace-element diagrams showing variation related to the degree of differentiation, as measured by the $\mathrm{MgO}$ content. Except for scandium and yttrium, the Hole 647A samples appear to be depleted in hafnium, zirconium, tantalum, and REEs relative to the Davis Strait suite at the same level of differentiation. 

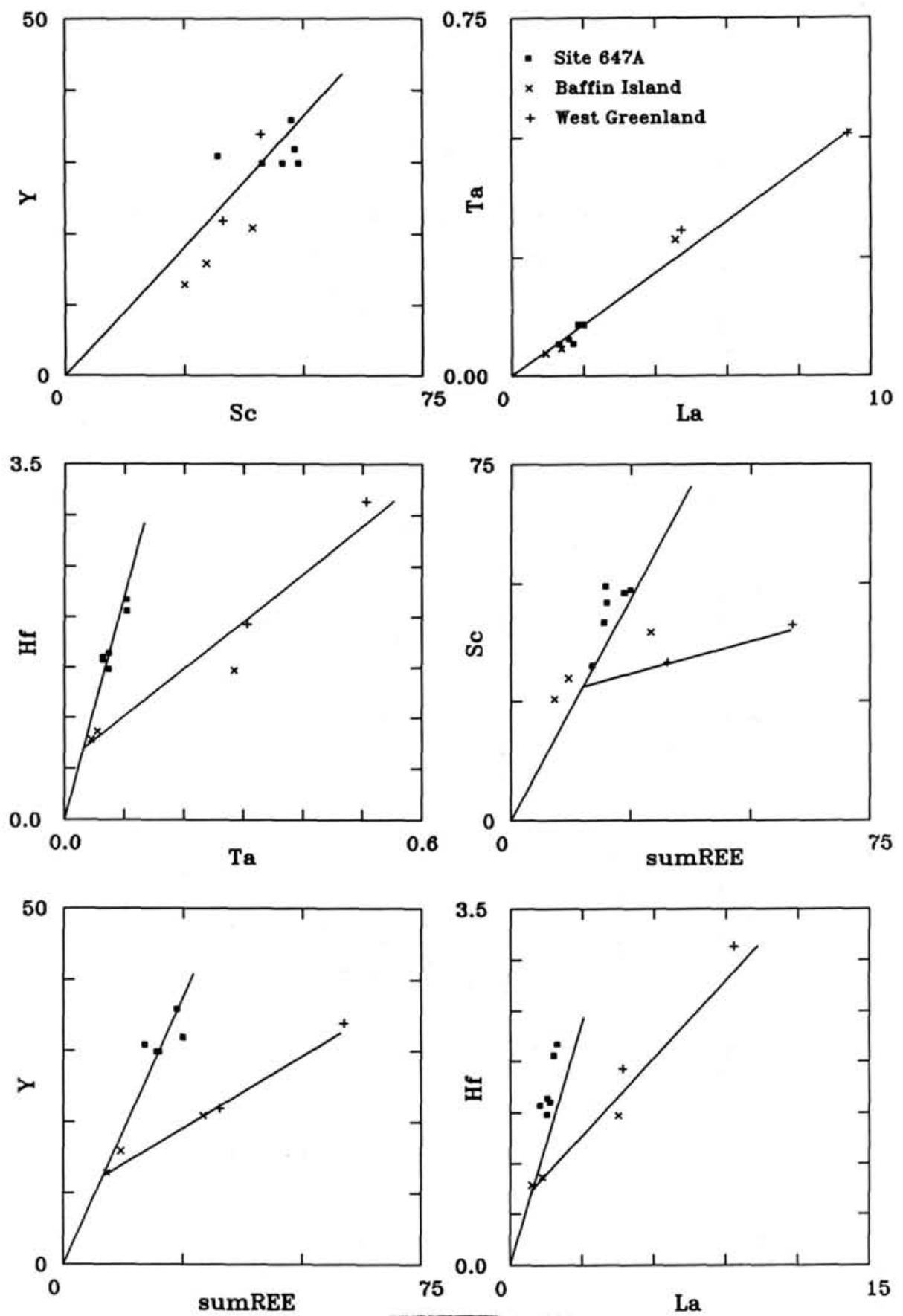

Figure 9. Incompatible trace-element plots illustrating the similarity of the Hole 647A and most primitive BI basalts. These rocks may have derived from similar mantle compositions and may be related by olivine fractionation. In contrast, the remainder of the BI-WG suite requires some other process to account for their departure from olivine control-lines (see text for details). 


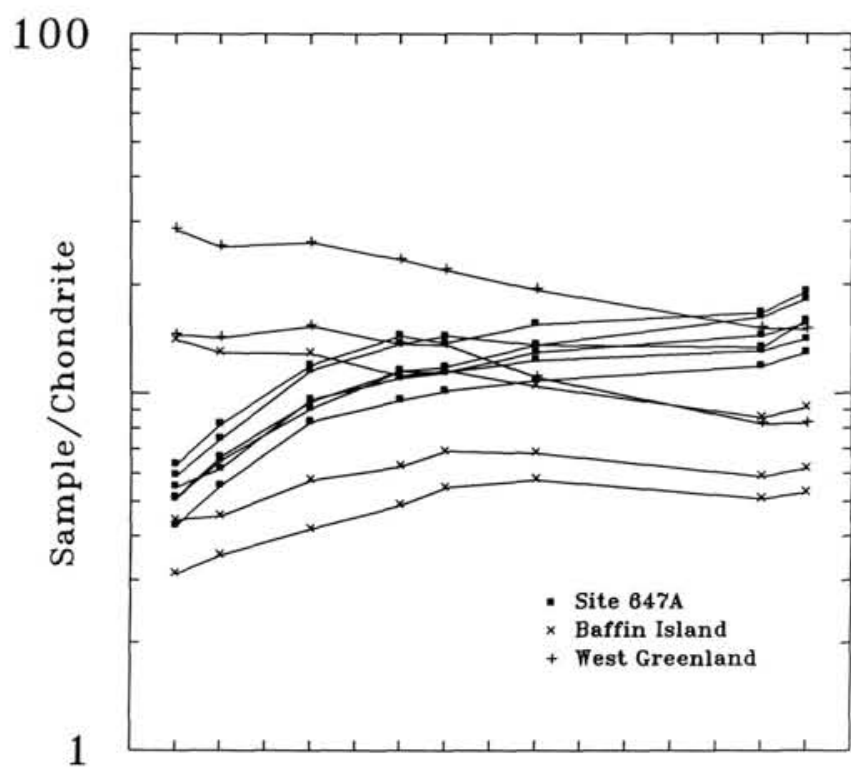

La Ce Pr Nd Sm Eu Gd Tb Dy Ho Er Tm Yb Lu

Figure 10. Conventional REE diagram showing that the Hole 647A basalts are typically light-REE-depleted and have concentrations that are intermediate between the BI and WG groups.

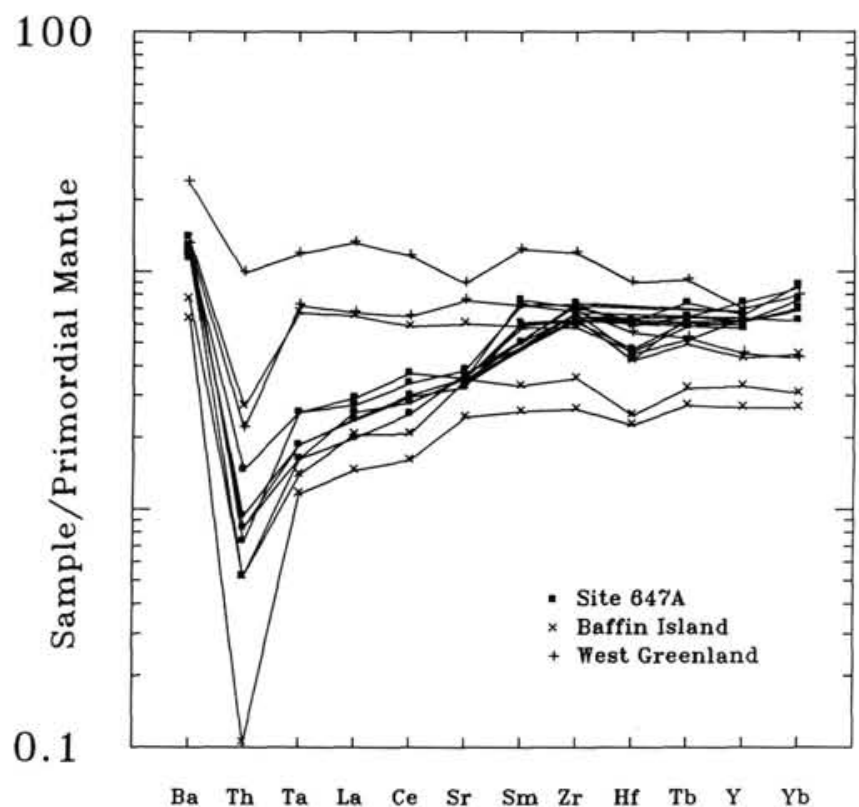

Figure 11. Spidergram illustrating that the Labrador Sea and Davis Strait basalts have rather flat patterns and low degrees of enrichment of the incompatible trace elements relative to the primordial mantle of Wood (1979), except that the ytterbium value is from Sun and Nesbitt (1977). This diagram suggests that all samples may have evolved from similar parent magmas with very little other than olivine fractionation to account for the differences in concentrations of the incompatible elements. 
A

$\mathrm{Ti} / 100$

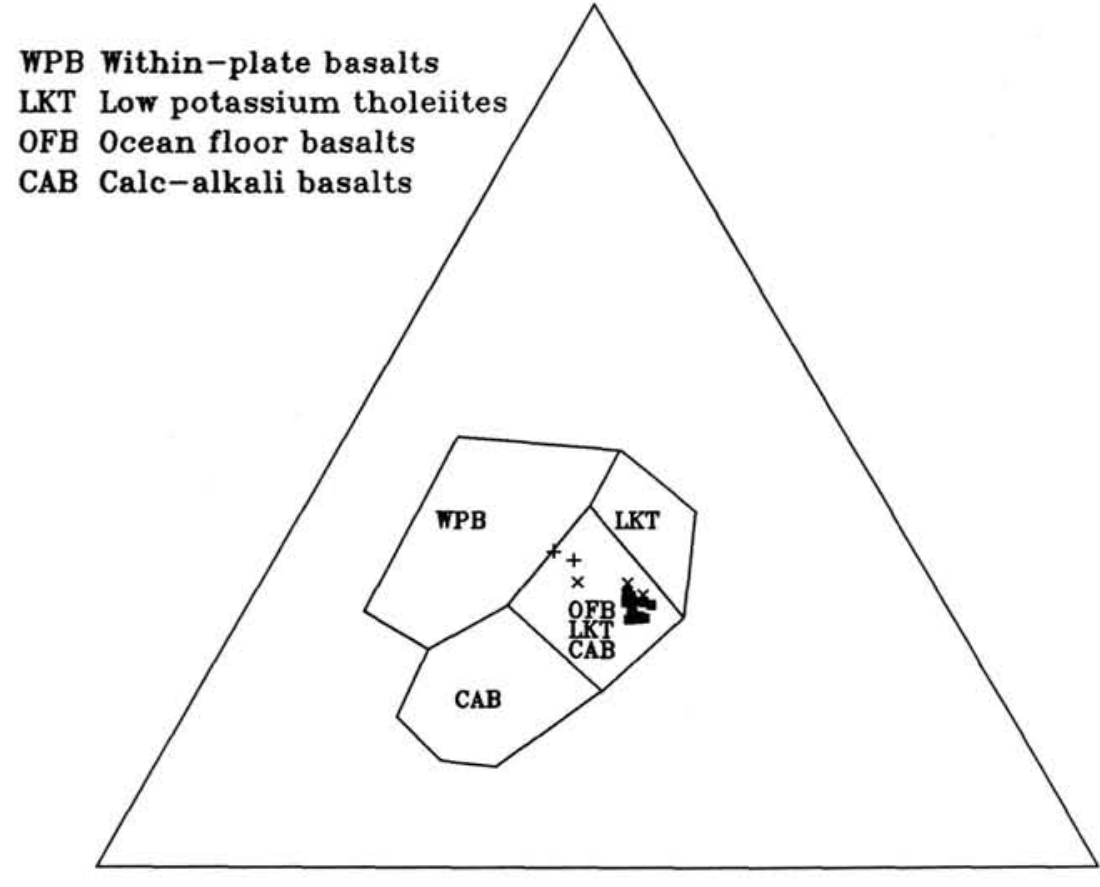

$\mathrm{Zr}$

$\mathrm{Y}^{*} 3$

B

$\mathrm{Ti} / 100$

- Site 647A

$\times$ Baffin Island

+ West Greenland

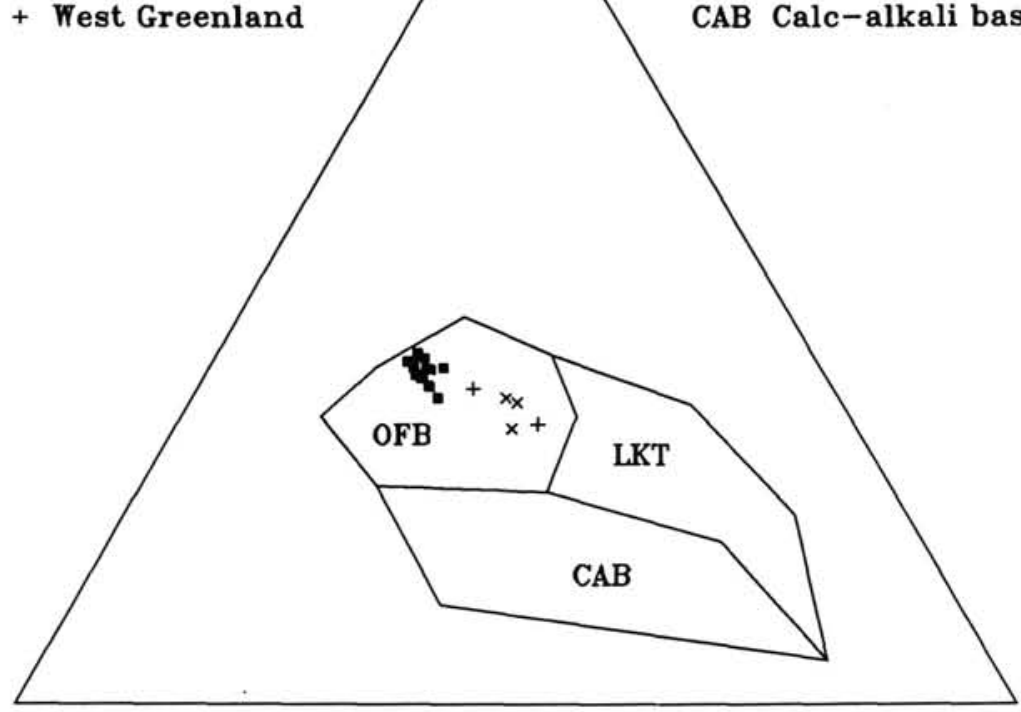

\section{$\mathrm{Zr}$}

$\mathrm{Sr} / 2$

Figure 12. Titanium-zirconium-yttrium and thorium-hafnium-tantalum plots of Pearce and Cann (1973) showing the similar compositions of the BI-WG and Hole 647A suites, again with the evolution of the WG samples toward "within-plate" characteristics as the volcanic pile thickened. 


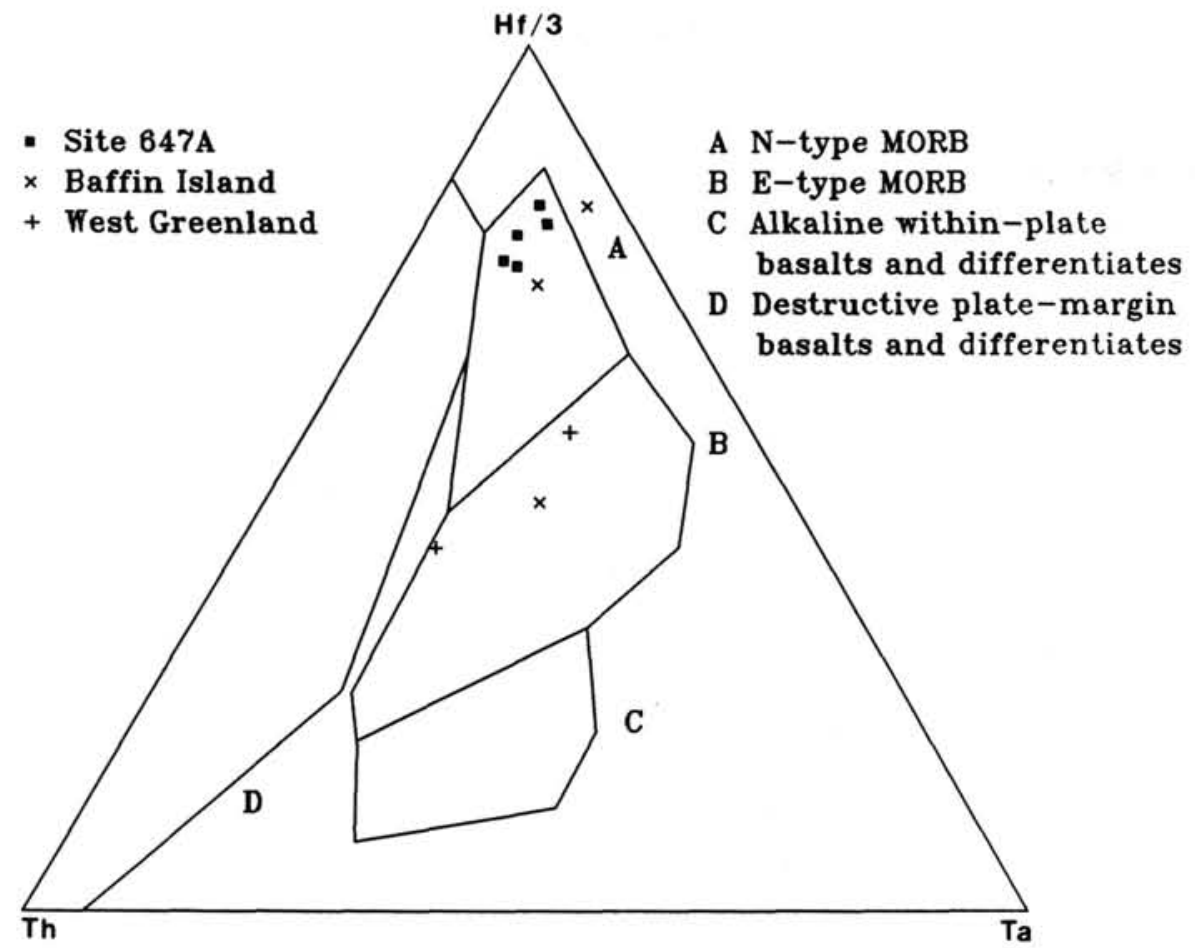

Figure 13. Thorium-hafnium-tantalum diagram of Wood (1980) showing the N-type MORB character of most of the Davis Strait and Labrador Sea basalts, with three of the Davis Strait samples plotting in the tholeiitic within-plate basalt field.

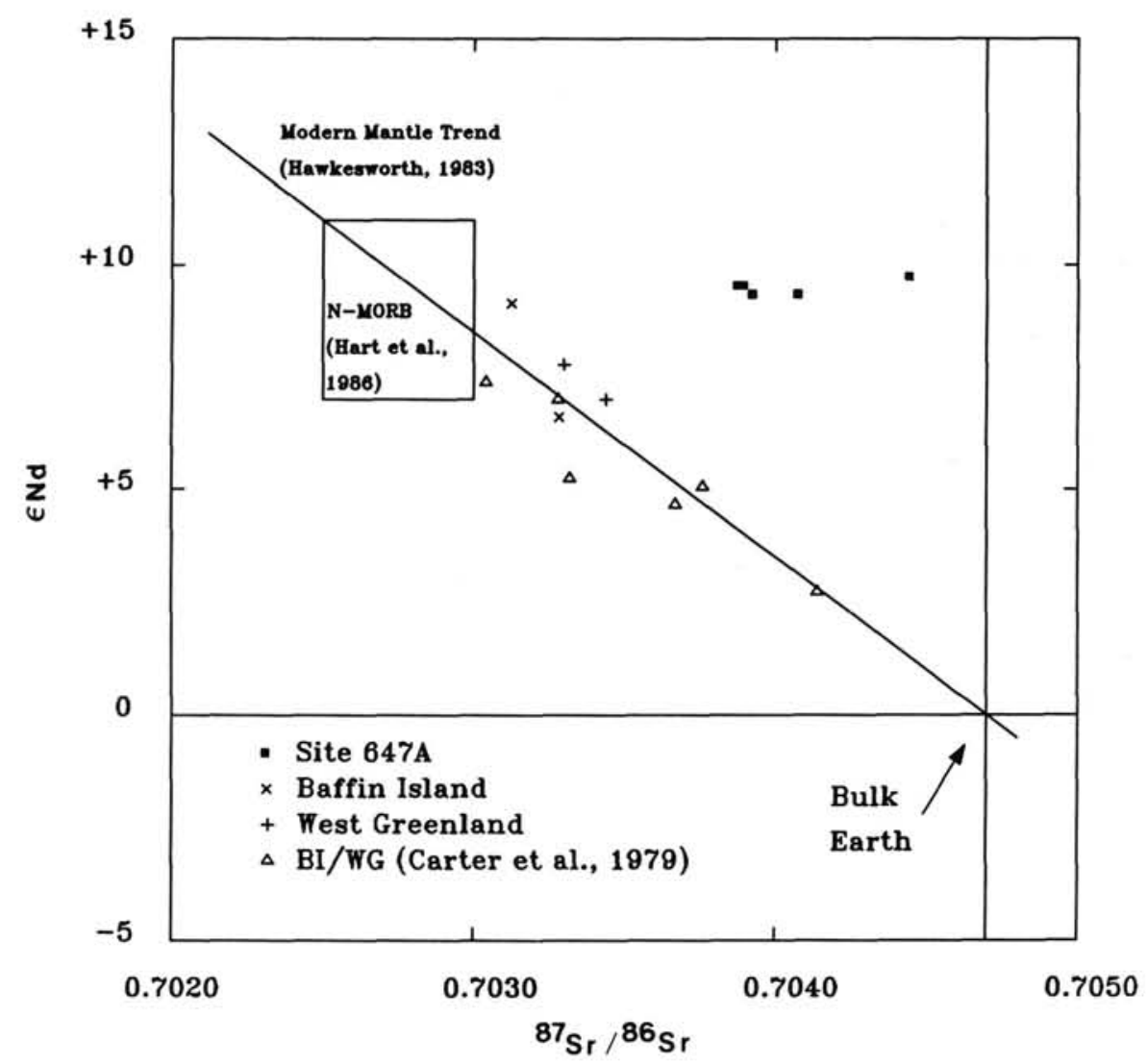

Figure 14. Strontium and neodymium isotopic diagram. The Davis Strait samples analyzed here combined with those of Carter et al. (1979) define a good approximation to the Modern Mantle Trend. Variation among these samples implies considerable differences in the degree of depletion of the mantle source region (see text). The Hole 647A samples appear to be enriched in ${ }^{87} \mathrm{Sr}$ relative to $\mathrm{N}$-type MORB and may not represent original mantle or magmatic compositions (see text). 


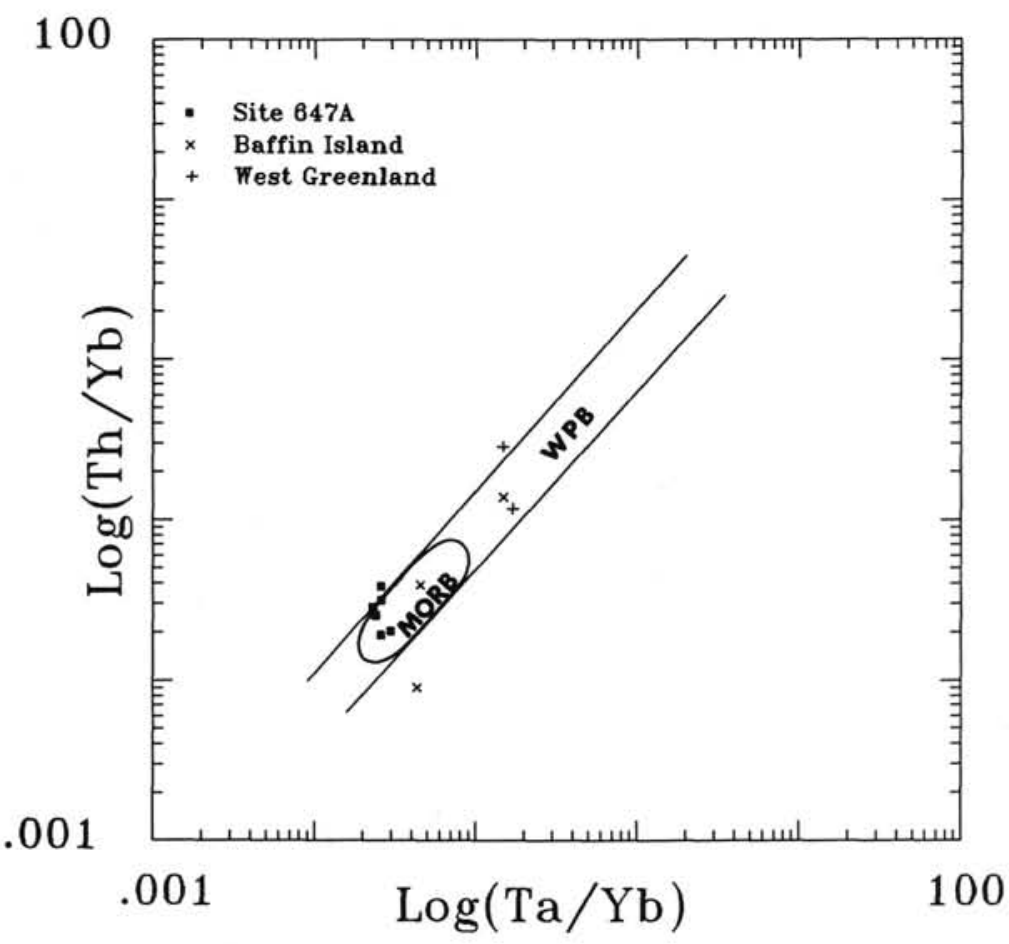

Figure 15. Thorium/ytterbium-tantalum/ytterbium diagram of Pearce (1983) to demonstrate the absence of a continental crustal component in the Hole 647A and Davis Strait basalts, even though the latter have demonstrably ascended through Precambrian basement. 

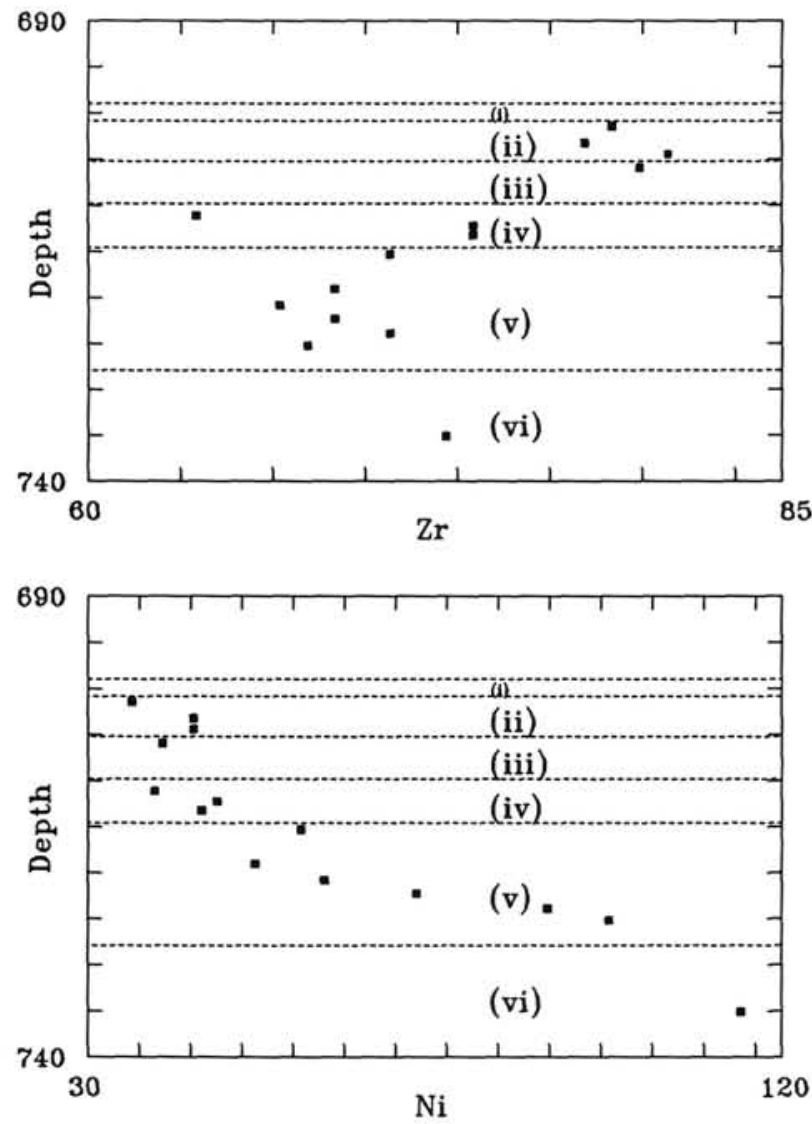

Figure 16. Composition and depth diagrams at Hole 647A. Although six textural variants can be recognized in the $37 \mathrm{~m}$ of core, the chemical variation requires no more than three eruptive or intrusive units to account for the observed variation.
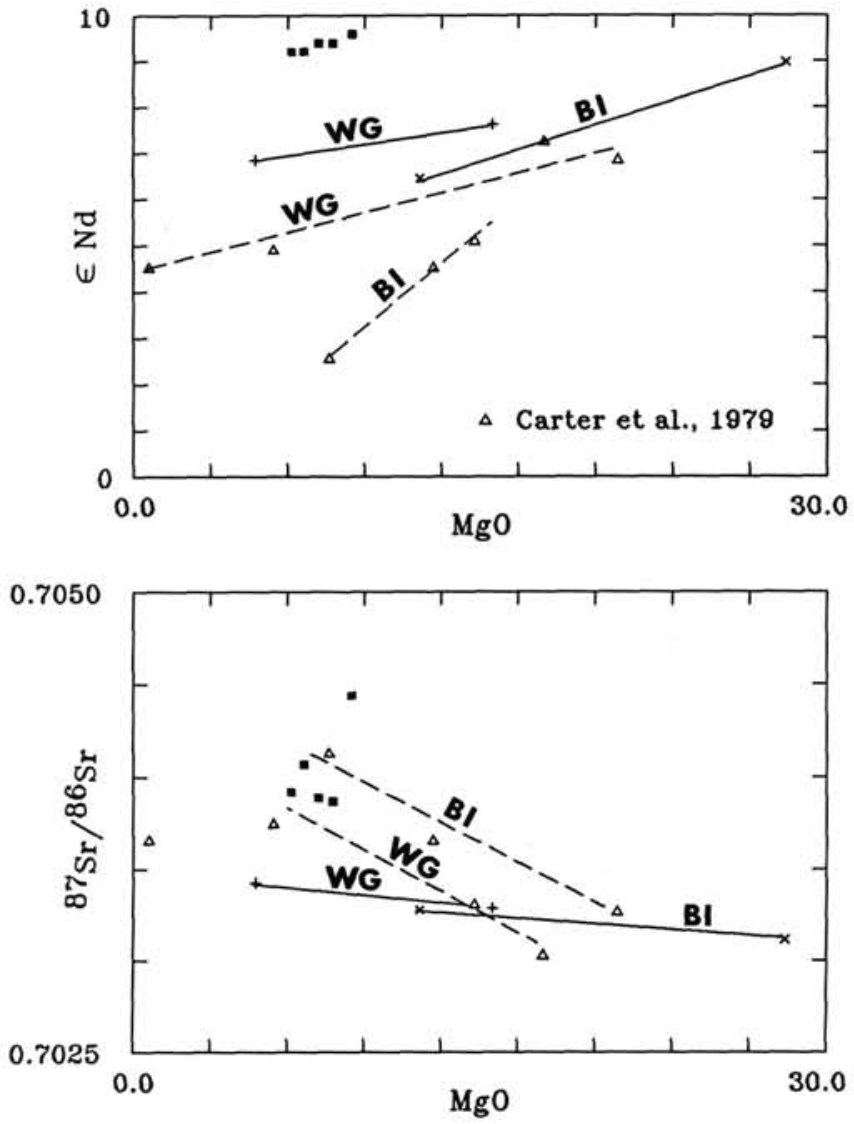

Figure 17. Isotopic variation as a function of major-element composition. The plots of $\mathrm{MgO}$ (compatible major element) and $\mathrm{TiO}_{2}$ (incompatible minor element), both of which vary systematically as a function of height in the volcanic piles, vs. the strontium and neodymium isotopic compositions indicate some variation in the isotopic composition of the lavas as a function of time.

Table 3. Major magmatic events in Labrador and Southwest Greenland.

\begin{tabular}{|c|c|c|c|}
\hline Formation/Group & $\begin{array}{l}\text { Age } \\
\text { Ma }\end{array}$ & $\left({ }^{87} \mathrm{Sr} /{ }^{86} \mathrm{Sr}\right)_{\mathrm{i}}$ & Reference \\
\hline $\begin{array}{l}\text { Various minor igneous } \\
\text { events in Newfoundland, } \\
\text { Labrador, Baffin Island, } \\
\text { and West Greenland }\end{array}$ & $765-115$ & - & $\begin{array}{l}\text { reviewed in Clarke (1977) } \\
\text { Hansen (1980) }\end{array}$ \\
\hline Gardar Alkaline & $1120-1350$ & 0.7033 & Emeleus and Upton (1976) \\
\hline $\begin{array}{l}\text { Magmatic Province, } \\
\text { Southwest Greenland }\end{array}$ & & & Upton et al. (1985) \\
\hline Mealy dykes, & $1460-1350$ & 0.7028 & Emslie et al. (1984) \\
\hline \multirow{3}{*}{$\begin{array}{l}\text { Shabogomo gabbro, and } \\
\text { anorthositic intrusions, } \\
\text { Labrador }\end{array}$} & & 0.7040 & Zindler et al. (1981) \\
\hline & & & Brooks et al. (1981) \\
\hline & & & Ashwal and Wooden (1985) \\
\hline $\begin{array}{l}\text { Snyder Group volcanic } \\
\text { breccia, Labrador }\end{array}$ & 1842 & 0.7044 & Barton and Barton (1975) \\
\hline $\begin{array}{l}\text { Ramah Group volcanic } \\
\text { member, Labrador }\end{array}$ & 1892 & $\begin{array}{l}0.7163 \\
(?)\end{array}$ & Morgan (1978) \\
\hline $\begin{array}{l}\text { Mugford Group } \\
\text { volcanics, Labrador }\end{array}$ & 2369 & 0.7033 & Barton (1975) \\
\hline Early Archean crust in & $2500-3800$ & - & Moorbath et al. (1975) \\
\hline Labrador and Southwest & & & Allaart (1976) \\
\hline \multirow[t]{5}{*}{ Greenland } & & & Bridgwater et al. (1976) \\
\hline & & & Hurst et al. (1977) \\
\hline & & & Taylor (1979) \\
\hline & & & Collerson and McCulloch (1982) \\
\hline & & & Ashwal et al. (1986) \\
\hline
\end{tabular}




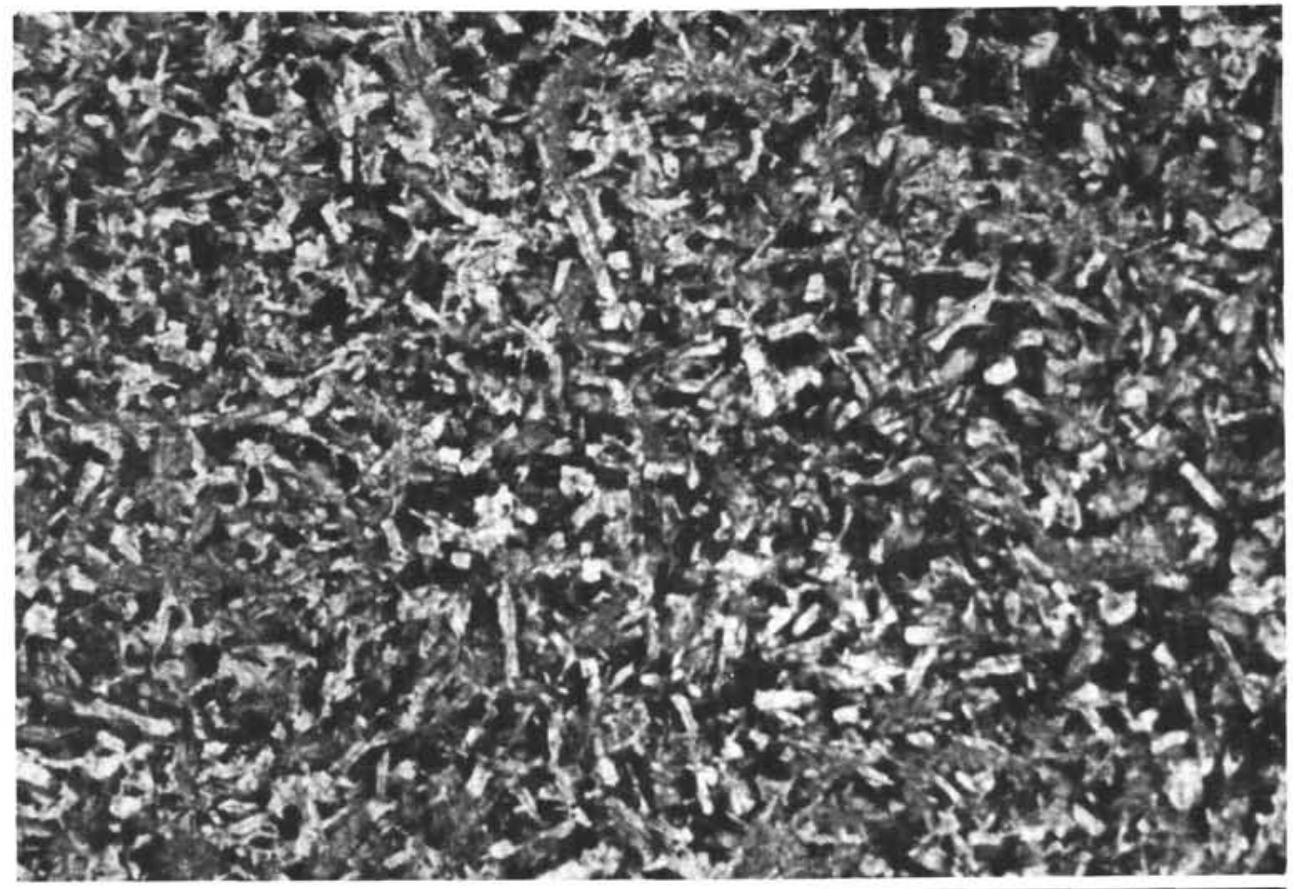

1

$5 \mathrm{~mm}$

Plate 1. Sample 105-647A-72R-2 is a fine-grained, aphyric basalt with an intergranular texture (Aphyric I) and white plagiocase laths (bytownite, clouded clinopyroxene (augite), and abundant equant opaques (titanomagnetite).

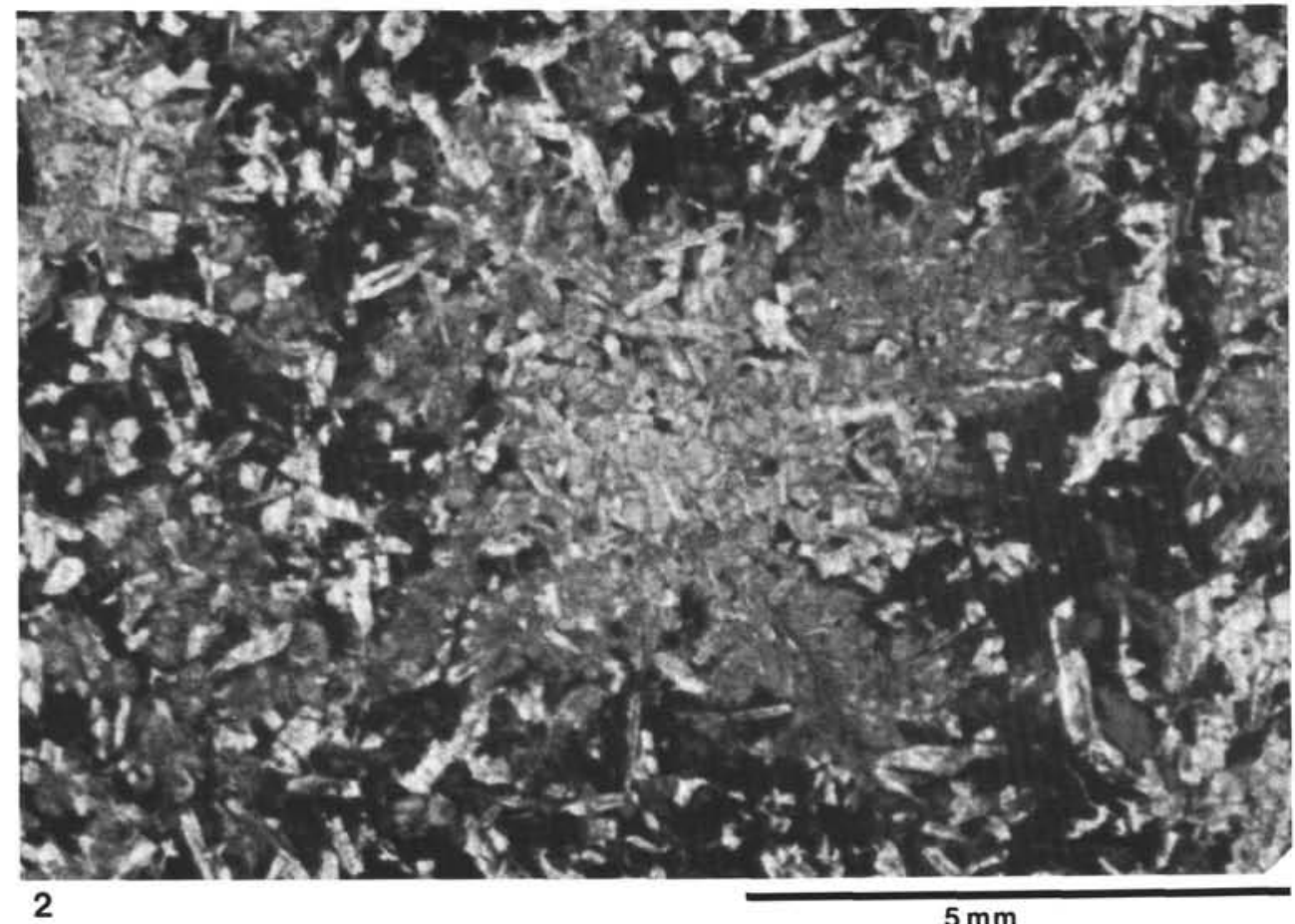

Plate 2. Sample 105-647A-72R-4 is a medium-grained, slightly pyroxene-phyric basalt having an intergranular texture characteristic of the glomerophyric textural type. 


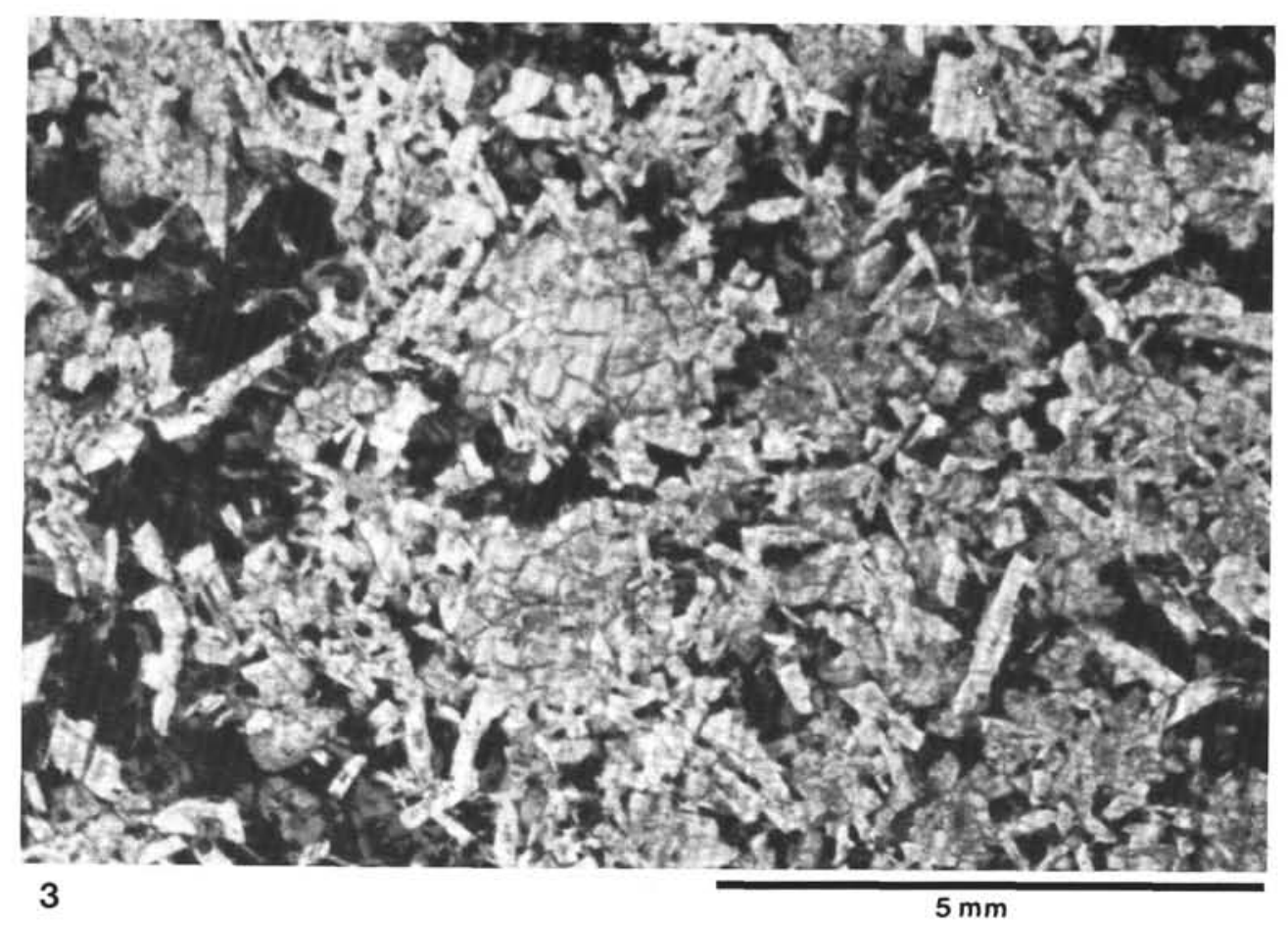

Plate 3. Sample 105-647A-73R-5 displays the features of the clinopyroxene-phyric textural type. This fineto medium-grained, porphyritic basalt, with microphenocrysts of poikilitic clinopyroxene and an intergranular groundmass, contains brown interstitial patches of altered glass.

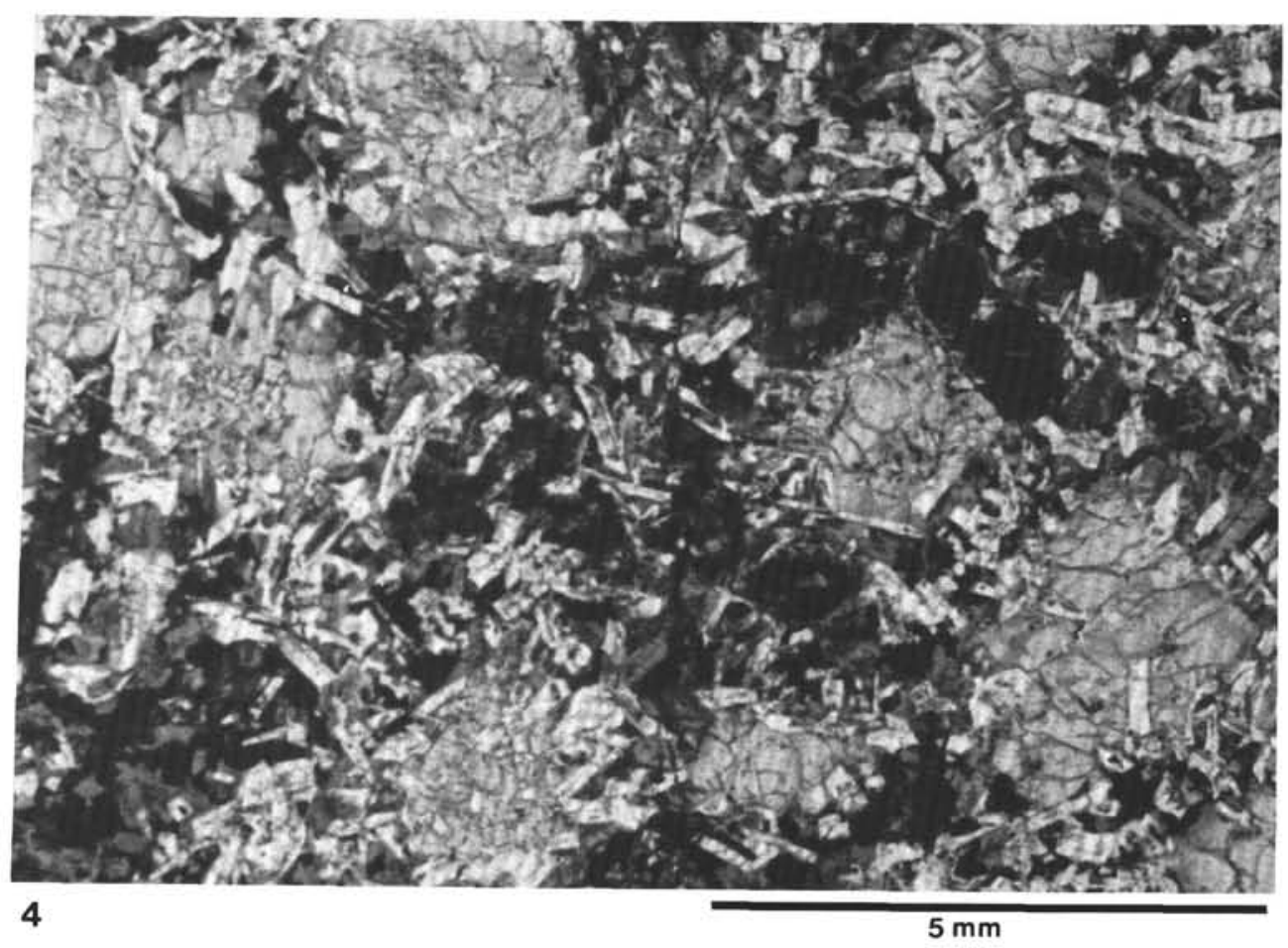

Plate 4. Sample 105-647A-74R-2 best shows the glomeroporphyritic textural type. The fine-grained basalt is distinguished by clusters of poikilitic clinopyroxene phencrysts in a subophitic to intergranular groundmass, and a modal increase in olivine pseudomorphs (circular grains with black rims and light gray cores). 